\title{
Thin layers of phytoplankton and harmful algae events in a coastal upwelling system
}

\author{
Esperanza Broullón ${ }^{\text {a,*, Marta López-Mozos }}{ }^{\mathrm{a}}$, Beatriz Reguera ${ }^{\mathrm{b}}$, Paloma Chouciño ${ }^{\mathrm{a}}$, \\ María Dolores Doval $^{\mathrm{c}}$, Bieito Fernández-Castro ${ }^{\mathrm{d}, \mathrm{e}}$, Miguel Gilcoto $^{\mathrm{f}}$, Enrique Nogueira ${ }^{\mathrm{b}}$, \\ Carlos Souto $^{g}$, Beatriz Mouriño-Carballido ${ }^{a}$ \\ a Departamento de Ecoloxía e Bioloxía Animal, Universidade de Vigo, Campus as Lagoas-Marcosende, 36310 Vigo (Pontevedra), Spain \\ ${ }^{\mathrm{b}}$ Centro Oceanográfico de Vigo, Instituto Español de Oceanografía (IEO), Subida a Radio Faro 50, 36390 Vigo (Pontevedra), Spain \\ ${ }^{\mathrm{c}}$ Instituto Tecnolóxico para o Control do Medio Mariño, Peirao de Vilaxoán, 36611 Vilagarcía de Arousa (Pontevedra), Spain \\ d Physics of Aquatic Systems Laboratory, Margaretha Kamprad Chair, Institute of Environmental Engineering, École Polytechnique Fédérale de Lausanne, Lausanne, \\ Switzerland \\ e Ocean and Earth Science, University of Southampton, Southampton, UK \\ ${ }_{\mathrm{f}}^{\mathrm{f}}$ Instituto de Investigaciones Marinas, Consejo Superior de Investigaciones Científicas (CSIC), Eduardo Cabello 6, 36208 Vigo (Pontevedra), Spain \\ ${ }^{\mathrm{g}}$ Departamento de Física Aplicada, Universidade de Vigo, Campus as Lagoas-Marcosende, 36310 Vigo (Pontevedra), Spain
}

\section{A R T I C L E I N F O}

\section{Keywords:}

Thin layers of phytoplankton (TLP)

Dinophysis acuminata

Pseudo-nitzschia

Logistic Regression

Stratification

NW Iberian upwelling system

Galician Rías

\begin{abstract}
A B S T R A C T
We combined time-series from a monitoring program and specific field observations in order to: 1) describe the characteristics of thin layers of phytoplankton (TLP) in the Galician Rías Baixas (NW Iberian Peninsula), 2) investigate the relationship between spatially-extended TLP (se-TLP) events and environmental variables, and 3) analyze the relationship between TLP occurrence and cell densities of toxin-producing harmful algal bloom (THAB) species. Between 2012 and 2015, a total of 118 TLP were detected in any of the 39 stations weekly sampled in the study area in the frame of the monitoring program, which represents a frequency of occurrence of $2 \%$. Most TLP (84\%) were detected between May-August and located slightly below shallow pycnoclines. Eight se-TLP events, i.e., when at least five stations were simultaneously influenced by the occurrence of a TLP, were identified during the period 2012-2015. Six out eight of these events happened during summer-upwelling conditions, and according to a Principal Component Analysis (PCA) they were positively correlated with thermal stratification. The other two events, detected during spring-downwelling, were positively correlated with haline stratification. A logistic regression model including six variables (surface temperature, relative humidity, bottom salinity, a proxy for the intrusion of the Miño River plume into Ría de Vigo, Miño River flow, and bottom temperature) explained $42 \%$ of the variance in the occurrence of se-TLP events. The temporal persistence of TLP events was confirmed by observations carried out during specific cruises, which showed how TLP were formed and disappeared over short periods of time in response to changes in vertical mixing. TLP were more frequently observed in Ría de Pontevedra, which was characterized by longer harvesting closures due to detection of Dinophysis toxins (DSP: diarrhetic shellfish poisoning toxins and pectenotoxins) above regulatory levels. About $25 \%$ of the TLP detected in the Rías Baixas were associated with increased cell densities of potentially toxic Pseudo-nitzschia species (ASP: amnesic shellfish poisoning) and of $D$. acuminata. These results suggest that a relationship may be established between the occurrence of TLP and the growth and/or accumulation of the main THAB species in the Galician Rías Baixas.
\end{abstract}

\section{Introduction}

The Galician Rías are four flooded river valleys located at the northernmost end of the Canary Current-Iberian upwelling system
(Fraga, 1981; Ríos et al., 1992). This upwelling region, located at the Eastern boundary of the North Atlantic subtropical gyre, extends from Cape Verde Islands to the northwest of the Iberian Peninsula (Arístegui et al., 2009). Upwelling along the western Iberian coast is seasonal, due

\footnotetext{
* Corresponding author at: Departamento de Ecoloxía e Bioloxía Animal, Universidade de Vigo, 36310 Vigo, Spain.

E-mail address: esperanza.broullon.mandado@uvigo.es (E. Broullón).
} 
to the latitudinal displacement of the trade winds system (Wooster et al., 1976). In spring-summer, predominant northerly winds favour upwelling, whereas the fall-winter period is characterized by a predominance of southerly winds and downwelling conditions (Wooster et al., 1976). Despite the seasonal character of both regimes, $70 \%$ of the variability in wind conditions occurs in periods of less than 30 days (Álvarez-Salgado et al., 2003, 2002). In fact, the upwelling/downwelling episodes are short events $(\sim 3$ days) more likely to be present in their respective season but not unusual the rest of the year (Gilcoto et al., 2017).

Nutrient fertilization associated with northerly winds and the increase in solar radiation during the spring-summer months promote high primary production (Tilstone et al., 1999), which sustains an important fishing and shellfish activity (Figueiras et al., 2002). Mussel (Mytilus galloprovincialis) production of $\sim 250,000 \mathrm{t} \mathrm{year}^{-1}$ in the Rías Baixas represents $95 \%$ of the Spanish and $50 \%$ of the European production, making this region one of the top mussel producers in the world (Labarta and Fernández-Reiriz, 2019).

This production is jeopardized every year due to the occurrence of toxin-producing harmful algal blooms (hereafter referred to as THAB). These blooms cause lengthy harvesting closures due to the accumulation of Lipophilic (diarrhetic shellfish poisoning or DSP toxins, i.e., okadaic acid or OA and dinophysistoxins or DTXs, and pectenotoxins or PTXs), Amnesic (or ASP) and, to a lesser extent, Paralytic (or PSP) Shellfish Poisoning toxins (Blanco et al., 2019; Míguez et al., 1996; Trainer et al., 2010). Most harvesting closures are due to the accumulation of lipophilic toxins from Dinophysis species, in particular from $D$. acuminata (Reguera et al., 2014). High levels of okadaic acid (OA) produced by this species cause closures that may last up to nine months per year at hot spots in Ría de Pontevedra (Blanco et al., 2019).

Dinoflagellate species belonging to the genus Dinophysis (D. acuminata, D. acuta and D. caudata, among others) are low biomass THAB species, able to cause accumulation of lipophilic toxins (above regulatory levels) in shellfish at densities of $10^{2}-10^{3}$ cell $\mathrm{L}^{-1}$ (Reguera et al., 2014). Among them, D. acuminata stands out since this species is able to attain high abundance and persistence. Species of the D. acuminata complex have a cosmopolitan distribution, being present in tropical, temperate and boreal waters. In the Galician Rías, the occurrence of $D$. acuminata populations have been found to be tightly coupled to the upwelling season (Velo-Suárez et al., 2014). Dinophysis species are mixotrophs which need light, nutrients and live prey. Their nutritional behavior involves a food chain with three links. Dinophysis species feed on the ciliate Mesodinium rubrum which, in turn, feeds on cryptophyte microalgae, from which Dinophysis and Mesodinium obtain their kleptochloroplasts to perform photosynthesis (Park et al., 2006). D. acuminata populations are often located at the surface layer, where irradiance is maximal, co-occurring at times with their prey (Crawford, 2007; Díaz et al., 2019).

Pseudo-nitzschia is a globally distributed genus of pennate diatoms, including species with the ability to produce domoic acid, a neurotoxin that can result in ASP (Hasle, 1994; Lelong et al., 2012). These diatoms are characterized by forming colonies which organize as laddered chains, where each elongated cell is in contact with the previous and the following one through the extremes, propagating a reptant movement from one cell to another (Hasle, 1994). Blooms of Pseudo-nitzschia spp. are high biomass THAB, reaching densities of about $10^{5}-10^{6}$ cell $\mathrm{L}^{-1}$ (Trainer et al., 2012). They occur more frequently during the upwelling season, when the uplift of sub-surface water brings colonies or their spores to the surface/sub-surface where light and nutrient levels are sufficient to promote growth (Anderson et al., 2006; Fryxell et al., 1997; Lelong et al., 2012). Among the 37 Pseudo-nitzschia species known around the world (Lelong et al., 2012), at least 7 are present in the Galician Rías (Fraga, 1998), but ASP outbreaks in the area are mainly attributed to $P$. australis (Míguez et al., 1996; Trainer et al., 2010).

Finally, the dinoflagellates Alexandrium minutum and Gymnodinium catenatum are the main producers of PSP toxins in the region. Alexandrium minutum grows mainly in spring, in embayments somehow protected from the upwelling circulation (upwelling shadows), under the influence of freshwater inputs (Bravo et al., 2010). On the contrary, G. catenatum occurs by the end of summer-autumn and its blooms in the Rías have been associated with advection of previously established shelf populations (Fraga et al., 1988; Sordo et al., 2001).

Therefore, THAB species in the region exhibit a seasonal variability. First toxic events occur in spring, following the increase in solar radiation and the onset of water column stratification. Sinking diatom populations advected offshore by the upwelling circulation and their spores, may be reintroduced in the system during the next upwelling event (Pitcher, 1990). A second peak in autumn is mainly attributed to advection of shelf populations during downwelling conditions (Barton et al., 2016; Crespo et al., 2006; Escalera et al., 2010). Overall, proliferations of large diatoms, including Pseudo-nizschia species, extend from spring to summer during the upwelling season. During this period, proliferations of different Dinophysis species also occur. Later, coinciding with the autumn transition to the downwelling season, dinoflagellates, including Gymnodinium catenatum, dominate the phytoplankton community (Figueiras et al., 2002).

Some THAB species are capable of forming thin layers of phytoplankton (TLP) (McManus et al., 2003; Ryan et al., 2008, 2010; Steinbuck et al., 2010). These are a particular case of blooms where high cell densities are located within a narrow depth interval (from some centimeters to a few meters), which can extend horizontally over several kilometers and persist for several days (Dekshenieks et al., 2001; Durham and Stocker, 2012). A number of independent criteria have been proposed for their definition, most of which share three requirements: (1) the cells aggregation must be spatially and temporally persistent, i.e., TLP must be present in at least two consecutive vertical profiles (sampled within a few hours interval), (2) the layer thickness must not exceed a threshold (usually $<5 \mathrm{~m}$ ), and (3) the maximum concentration must exceed a certain value (i.e., three times the background levels -average chlorophyll or cell abundance- in the water column) (Dekshenieks et al., 2001; Sullivan et al., 2010b). Several physical and biological mechanisms, as well as a combination of both, have been proposed as responsible for the formation of TLP (Durham and Stocker, 2012), which are frequently associated with sharp pycnoclines.

TLP influence ocean ecological processes in different ways. As trophic hotspots, they can mediate the survival and reproduction rates of organisms belonging to higher trophic levels (Lasker, 1975). TLP are also believed to play an important role in the long-term maintenance and sudden formation of THAB (GEOHAB, 2008). The transport of subsurface thin layers of harmful species, located in the mouth of the Galician Rías, to inshore surface areas by upwelling events has been proposed as one of the seeding processes responsible for the formation of THAB in the region (Sellner et al., 2003; Velo-Suárez et al., 2014). Monitoring programs based either on oceanographic-bottle samples taken at specific depth intervals, or on integrated water-column tubesamples, miss TLP detection and may not appreciate the real magnitude of this type of blooms (Escalera et al., 2012; McManus et al., 2008; VeloSuárez et al., 2008), offering limited advice to alert shellfish managers.

A limited number of studies have described the occurrence of TLP in the Galician Rías so far. Velo-Suárez et al. (2008) described the formation of a TLP of toxin-producing Pseudo-nitzschia species (P. australis and $P$. cf delicatissima) and other diatoms during May-June 2005 in Ría de Pontevedra. This layer, associated with a steep pycnocline and high levels of shear and stratification, developed after an upwelling event, and was displaced downwards and eroded during downwelling. These observations were consistent with the mechanism of straining by shear playing a major role on its formation (Velo-Suárez et al., 2010). A later study carried out at the same station in May-June 2007 noted the role of small time-scale physical processes, e.g., the tidal cycle and intensity, in the modulation of TLP dynamics during a Pseudo-nitzschia spp. bloom (Díaz et al., 2014).

Despite existing evidence, our knowledge about the frequency of 
occurrence of TLP in the Galician Rías, the mechanisms of formation, and their ecological relevance is still largely incomplete. Here we combined time-series of monitoring data and research-cruise observations in order to: 1) describe the characteristics of TLP in the Galician Rías, 2) investigate the relationship between spatially-extended TLP (seTLP hereinafter) events and environmental variables, and 3) analyze the relationship between the occurrence of TLP and THAB species densities.

\section{Methods}

\subsection{Time-series analysis}

Data collected by the INTECMAR (Instituto Tecnolóxico para o Control do Medio Mariño, http://www.intecmar.gal) HAB monitoring program between January 2012 and December 2017 were used (Fig. 1). This program includes a weekly sampling of physical, chemical and biological variables (e.g., chlorophyll fluorescence), as well as analyses of THAB species, on 39 stations covering the main zones of raft-mussel production in the Galician Rías Baixas (Vigo, Pontevedra, Arousa and Muros-Noia).

\subsubsection{Hydrographic and meteorological data}

At each station, hydrographic information was obtained at $8 \mathrm{~Hz}$ with a SeaBird (SBE-25) Conductivity-Temperature-Depth (CTD) profiler equipped with a WETStar fluorescence sensor. Temperature and salinity raw data were vertically averaged every $1 \mathrm{dbar}$ and low-pass filtered (by a 3 dbar window moving average). For each profile, the mean density stratification was calculated as the ratio of surface-bottom differences of density and pressure. Surface properties were considered as the average in the upper 3 dbar. Because the profiles did not reach the same depth in all samplings, bottom pressure was considered as the minimum of the maximal pressure reached for all samplings conducted at each station.

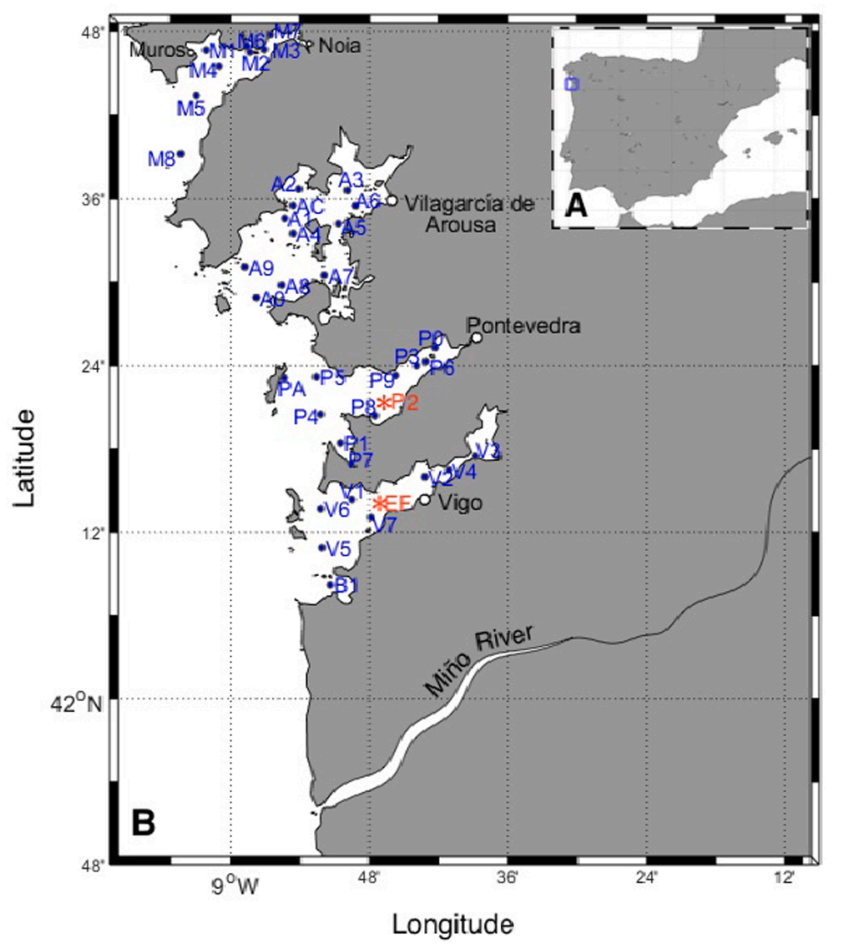

Fig. 1. (A) Map of the study area showing the Iberian Peninsula and (B) the Rías Baixas. Dots indicate the stations sampled weekly by the INTECMAR monitoring program. P2 (Bueu) and EF are indicated in red color as additional field observations were carried out at these stations (see methods). (For interpretation of the references to color in this figure legend, the reader is referred to the web version of this article.)
Bottom properties were obtained as the average of the 3 dbar above the maximal pressure. Thermal and haline stratification were estimated with the same procedure. After removing values above $3 \mathrm{dbar}$, the depth of maximal stratification was computed as the depth where vertical differences in the smoothed density profile were maximal.

Based on the procedure proposed by Sullivan et al. (2010a), we designed an algorithm to detect the occurrence of thin layers on the 1dbar averaged fluorescence profiles obtained between January 2012 and December 2015 at the 39 stations. The upper and lower extent of the thin layer was defined by finding the minimum and maximum of the first derivative, and then extending away from these points to a value that represented $30 \%$ of the maximum and minimum, as the derivative curves returned to zero (Fig. 2). Thin layers were defined as fluorescence features having a full-width-at-half-maximum (FWHM) peak value lower than $3 \mathrm{~m}$, and a total peak height 2 times higher than the estimated fluorescence background (B). B was calculated using a linear extrapolation between the top and bottom edges of the thin layer to the depth of its peak center. The difference between the fluorescence maximum and B is named the intensity above background (I). FWHM is the depth difference between those points above and below the fluorescence maximum where the fluorescence is equal to $\mathrm{I} / 2$. The algorithm detected all TLP that met these criteria and recorded relevant hydrographic features associated with the fluorescence profiles containing TLP. The HAB monitoring program includes a single CTD cast per station $(n=39)$. Therefore, it was possible to describe the spatial extent of the TLP, but not its temporal persistence due to the weekly scale of sampling.

Information about tidal variations of seawater level was obtained from REDMAR (Red de Medida del Nivel del Mar y Agitación by Puertos del Estado, http://www.puertos.es). The selected mareograph (Vigo, $42.24^{\circ} \mathrm{N}, 8.74^{\circ} \mathrm{W}$, station code 3221 ) has a sampling rate of one minute and is equipped with a radar. Available data on the website are averaged

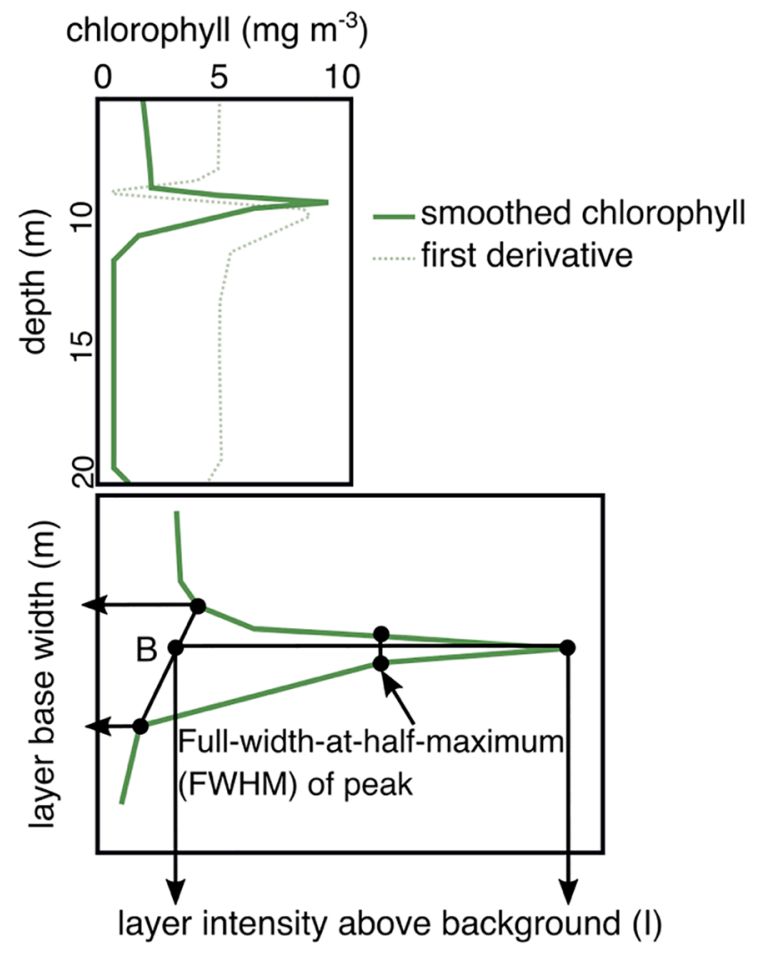

Fig. 2. A theoretical example of a vertical fluorescence profile of a thin layer of phytoplankton. The top plot shows a smoothed vertical profile of chlorophyll and its first derivate. Metrics applied to delimit these features include three characteristics showed in the bottom plot: background (B), full-width-at-halfmaximum (FWHM) of peak $(<3 \mathrm{~m})$ and layer intensity above background (I, $2 \mathrm{x}$ the estimated chlorophyll background). 
every five minutes. For each sampling date, the closer sea level data to the sampling time was chosen.

Discharges of the local rivers into each of the four rías that comprise the Galician Rías Baixas at the day of sampling were obtained from the SWAT (Soil Water Assessment Tool) model setup from Meteogalicia available at the THREDDS (Unidata's Thematic Real-time Environmental Distributed Data Services, https://www.unidata.ucar.edu) server in http://www.meteogalicia.gal. For those rías under the influence of more than one local river, discharges were calculated as the sum of all rivers. Data of the Miño River (located south of the Rías Baixas, Fig. 1) discharges, measured at the gauge station 1642-Salvatierra de Miño of the Confederación Hidrográfica del Miño-Sil (https://www.chm inosil.es), were provided by CETMAR (Centro Tecnológico del Mar, https://cetmar.org).

A proxy for the intrusion of the Miño River plume into Ría de Vigo was calculated based on the difference in surface salinity values between station V5 (outer part of the ría) and station V2 (inner part), as proposed by Des et al. (2019). Negative values of this proxy indicate the entrance of freshwater from the Miño River plume into the Ría.

Meteorological information (air temperature, relative humidity, precipitation, long-wavelength radiation, short-wavelength radiation and zonal and meridional wind components) was obtained from the meteorological model WRF (Weather Research Forecast, https://www. mmm.ucar.edu/) also available on THREDDS. Averaged daily values corresponding to the sampling dates and reference stations in Ría de Vigo $\left(42.21^{\circ} \mathrm{N}, 8.84^{\circ} \mathrm{W}\right)$, Pontevedra $\left(42.35^{\circ} \mathrm{N}, 8.86^{\circ} \mathrm{W}\right)$, Arousa $\left(42.51^{\circ} \mathrm{N}, 8.95^{\circ} \mathrm{W}\right)$ and Muros-Noia $\left(42.69^{\circ} \mathrm{N}, 9.06^{\circ} \mathrm{W}\right)$ were used for all the stations sampled at each Ría.

The Ekman transport for the zonal $\left(E t_{x}\right)$ and meridional $\left(E t_{y}\right)$ components was calculated from the mean daily wind velocities computed at a reference station located at the continental shelf $\left(42.42^{\circ} \mathrm{N}, 9.25^{\circ} \mathrm{W}\right)$, according to the equation proposed by Bakun (1973):

$E t_{x}=\frac{\tau_{y}}{f}=\frac{\rho_{a i r} \cdot C_{D} \cdot|V| \cdot V_{y}}{\rho_{s w} \cdot f}\left(m^{2} \cdot s^{-1}\right)$,

$E t_{y}=\frac{\tau_{x}}{f}=\frac{\rho_{a i r} \cdot C_{D} \cdot|V| \cdot V_{x}}{\rho_{s w} \cdot f}\left(m^{2} \cdot s^{-1}\right)$

where $\tau$ is the stress vector, $\rho_{\text {air }}$ the air density at $15^{\circ} \mathrm{C}\left(1.22 \mathrm{~kg} \mathrm{~m}^{-3}\right), \rho_{s w}$ the reference marine water density $\left(\sim 1025 \mathrm{~kg} \mathrm{~m}^{-3}\right), C_{D}$ an empirical drag coefficient, $V$ the estimated wind vector near the sea surface with magnitude $|V|$, and $f$ the Coriolis factor $\left(\operatorname{rad~s}^{-1}\right)$.

Assuming that there may be a delay in the occurrence of thin layers in response to environmental conditions, Ekman transport, the Miño River and the other rivers flow were averaged over the three days preceding the sampling date.

\subsubsection{Inorganic nutrients}

Water samples for the analysis of inorganic nutrients (nitrate, nitrite, ammonium, phosphate and silicate) and for phytoplankton counts were collected with a dividable PVC hose-sampler (Lindahl, 1986). This device collects integrated water samples from three depth intervals $(0-5 \mathrm{~m}$, 5-10 $\mathrm{m}$ and 10-15 m). Analysis of inorganic nutrients were based on the colorimetric method of continuous segmented flow analysis (CFA) proposed by Hansen and Grassoff, (1983) and updated for Quaatro analyser. Precision was $\pm 0.02 \mu \mathrm{mol} \mathrm{L} \mathrm{L}^{-1}$ for nitrite, $\pm 0.1 \mu \mathrm{mol} \mathrm{L}-1$ for nitrate, \pm $0.05 \mu \mathrm{mol} \mathrm{L}^{-1}$ for ammonium, $\pm 0.01 \mu \mathrm{mol} \mathrm{L}^{-1}$ for phosphate and \pm $0.06 \mu \mathrm{mol} \mathrm{L}^{-1}$ for silicate. Samples for inorganic nutrients analysis were not collected at stations EF (Ría de Vigo) and AC (Ría de Arousa). Values for these stations were calculated by inverse distance weighting interpolation using the values obtained at the nearest stations (V1-V7, and A1-A2, respectively).

\subsubsection{Phytoplankton analysis}

Phytoplankton cell counts, from January 2012 to December 2017 were obtained from the weekly reports published by the INTECMAR at the institute website (http://www.intecmar.gal). The monitoring program includes sampling to estimate phytoplankton cell density at all stations except EF and AC. Water samples for phytoplankton quantitative analyses were taken with the hose-sampler described before. Integrated $(0-15 \mathrm{~m})$ water samples were immediately fixed on board with acidic Lugol's iodine solution. Sedimentation chambers of $25 \mathrm{~mL}$ for each sample were left to settle overnight. Cell counts were carried out with an inverted microscope, according to the Utermöhl method (1958) as described in Moroño et al. (2008). Phytoplankton was determined to species level when possible. Transects were counted at x400 magnification to include the smaller and more abundant species. To count larger, less abundant (such as Dinophysis) species, the whole surface of the chamber was scanned at a magnification of $\mathrm{x} 100$, so that the detection limit was $40 \mathrm{cel} \mathrm{L}^{-1}$. Toxin-producing phytoplankton species/ genera analyzed included those labeled as Pseudo-nitzschia spp., Alexandrium spp., Gymnodinium catenatum, Dinophysis acuminata, Dinophysis acuta, Dinophysis caudata and Dinophysis spp in the monitoring cell counts.

\subsection{Statistical analysis}

Taking into account that $99 \%$ of TLP were detected between March and September, the statistical analyses for the 2012-2015 period were carried out only for these months. Missing data were dealt with by a listwise deletion mechanism under the missing completely at random (MCAR) data assumption. A total of 2502 observations were finally used.

\subsubsection{Principal component analysis}

The relationship between the environmental variables and the occurrence of se-TLP events, when at least five stations were simultaneously influenced by the occurrence of a TLP, was explored using a Principal Component Analysis (PCA). A set of 26 variables were included in the analysis (Table 1). Due to scale differences, variables were standardized prior to the analysis. PCA was performed using the Fathom Toolbox for MATLAB (Jones, 2015).

\subsubsection{Logistic regression}

In order to quantify the variance in the occurrence of se-TLP events

Table 1

Variables (units) included in the Principal Component Analysis and their code.

\begin{tabular}{|c|c|}
\hline Variable & Code \\
\hline Surface temperature $\left({ }^{\circ} \mathrm{C}\right)$ & Tsurf \\
\hline Surface salinity (PSU) & Ssurf \\
\hline Bottom temperature $\left({ }^{\circ} \mathrm{C}\right)$ & Tbot \\
\hline Bottom salinity (PSU) & Sbot \\
\hline Bottom pressure (dbar) & Pflu \\
\hline Pressure at maximum of stratification (dbar) & PStr \\
\hline Intensity of thermic stratification $\left({ }^{\circ} \mathrm{C} \mathrm{dbar}^{-1}\right)$ & StrT \\
\hline Intensity of haline stratification (PSU $\mathrm{dbar}^{-1}$ ) & StrH \\
\hline Air temperature $\left({ }^{\circ} \mathrm{C}\right)$ & Tair \\
\hline Relative humidity (\%) & RH \\
\hline Precipitation $\left(\mathrm{L} \mathrm{m}^{-2}\right)$ & Prec \\
\hline Short-wave radiation $\left(\mathrm{W} \mathrm{m}^{-2}\right)$ & RadSw \\
\hline Long-wave radiation $\left(\mathrm{W} \mathrm{m}^{-2}\right)$ & RadLw \\
\hline Local wave wind in $\times\left(\mathrm{m} \mathrm{s}^{-1}\right)$ & Wx \\
\hline Local wave wind in $y\left(\mathrm{~m} \mathrm{~s}^{-1}\right)$ & Wy \\
\hline Sea Level (cm) & Ltide \\
\hline Miño river flow $\left(\mathrm{m}^{3} \mathrm{~s}^{-1}\right)$ & RfM \\
\hline Local river flow $\left(\mathrm{m}^{3} \mathrm{~s}^{-1}\right)$ & RfL \\
\hline Ekman transport in $\times\left(\mathrm{m}^{3}(\mathrm{~km} \mathrm{~s})^{-1}\right)$ & Etx \\
\hline Ekman transport in $y\left(\mathrm{~m}^{3}(\mathrm{~km} \mathrm{~s})^{-1}\right)$ & Ety \\
\hline Freshwater entrance (PSU) & Prox \\
\hline Ammonium $\left(\mu \mathrm{mol} \mathrm{L}^{-1}\right)$ & NH4+ \\
\hline Phosphate $\left(\mu \mathrm{mol} \mathrm{L}{ }^{-1}\right)$ & Phosp \\
\hline Nitrate $\left(\mu \mathrm{mol} \mathrm{L}^{-1}\right)$ & Nitra \\
\hline Nitrite $\left(\mu \mathrm{mol} \mathrm{L}{ }^{-1}\right)$ & Nitri \\
\hline Silicate $\left(\mu \mathrm{mol} \mathrm{L}^{-1}\right)$ & $\mathrm{Si}$ \\
\hline
\end{tabular}


explained by the environmental conditions, a logistic regression model (logit model) was built. The logit model belongs to the Generalized Linear Models (GLM) family, and it is used when the response of the dependent variable is binary, e.g. presence or absence. In contrast to the linear probability model, the logit model introduces an exponential term into the regression and divides it by a denominator greater than itself, avoiding negative or higher than one probability results. In this way, the logistic regression model predicts the logarithm of the odds, i. e. the logarithm of the probability of occurrence versus the probability of nonoccurrence (Hosmer et al., 2013).

In our model, the binary dependent variable was the occurrence of se-TLP events ( $1=$ presence, $0=$ absence). The best subset of environmental variables and their interactions were selected based on a backward stepwise regression analysis and the Wald test. A first regression model selected twelve variables, that were reduced to eight based on the Wald test (significance level $\mathrm{p}<0.01$ ). These eight variables and their interactions were analyzed with a second backward stepwise regression analysis and the Wald test, which resulted in six selected variables and one interaction term.

The goodness-of-fit was evaluated using the Hosmer-Lemeshow test, which indicated that there were no significant differences between the observed and the predicted results $(\alpha=0.05 ; \chi 2 \mathrm{H}-\mathrm{L}=3.773$ and $\mathrm{p}=$ $0.876)$. None of the variables showed multi co-linearity, according to the computed variance inflation factor (VIF < 5) (James et al., 2013). No observation influenced the estimates of the model coefficients due to a disproportionate effect on it (Cook's distance $<1$ ) (Cook and Weisberg, 1982).

The logistic regression was carried out in using the R packages stats, vcdExtra and car, available on CRAN (https://cran.r-project.org/).

\subsection{TLP observations during specific field cruises}

Specific information about the occurrence of TLP in the Galician Rías was obtained from samplings carried out in the framework of the DISTRAL-REIMAGE and ASIMUTH projects. During DISTRAL-REIMAGE (February 2012-January 2013) 10 samplings were carried out at station $\mathrm{EF}\left(42.23^{\circ} \mathrm{N}, 8.79^{\circ} \mathrm{W}\right), 45 \mathrm{~m}$ depth at low tide in Ría de Vigo. During each sampling, hydrographic properties and turbulent dissipation rates were measured with a MSS90 microstructure turbulent profiler (Prandke and Stips, 1998). The MSS90 profiler is equipped with two microstructure shear sensors (type PNS06), a high-precision Conductivity-Temperature-Depth (CTD) probe, a fluorescence sensor, and a horizontal accelerometer. Ten microstructure turbulence profiles were carried out successively during each $\sim 25$ min sampling. An exception was made on May 14 when a more intense ( $3.7 \mathrm{~h}$ ) sampling ( 75 profiles) was carried out to describe a remarkable TLP present that day. During ASIMUTH (18-20 June 2013), observations of turbulence microstructure were obtained by using the same profiler during $36 \mathrm{~h}$ at a fixed station, P2 (Bueu, $42.36^{\circ} \mathrm{N}, 8.77^{\circ} \mathrm{W}$ ), $27 \mathrm{~m}$ deep at low tide in Ría de Pontevedra. In this case, a set of 5 profiles were conducted every 1-2 h.

The profiler was carefully balanced to have negative buoyancy in the water column and a sinking velocity of $0.3-0.7 \mathrm{~m} \mathrm{~s}^{-1}$. Turbulent kinetic energy dissipation rates $(\varepsilon)$ were computed in 512 data point segments, with $50 \%$ overlap, from the microstructure shear variance under the assumption of isotropic turbulence. The shear variance was computed by integrating the shear power spectrum. The lower integration limit was constrained by the size of the segments, and set to a minimum value of 2 cycles per meter (cpm). The upper cut-off wave number for the integration of the shear spectrum was set as the Kolmogorov number, which was determined by an iterative procedure. The maximum uppercutoff was not allowed to exceed $30 \mathrm{cpm}$ to avoid the noisy part of the spectrum. Assuming a universal form of the shear spectrum, $\varepsilon$ was corrected for the loss of variance below and above the used integration limits, using the polynomial functions (Prandke et al., 2000). Peaks due to particle collisions were removed by comparing the dissipation rates computed simultaneously from the two shear sensors, which were finally averaged. The squared Brunt-Väisälä frequency $\left(N^{2}\right)$ was derived from the CTD profiles according to the equation:

$N^{2}=-\frac{\mathrm{g}}{\rho_{w}} \cdot \frac{\partial \rho}{\partial z}\left(s^{-2}\right)$

where $g$ is the acceleration due to gravity $\left(9.8 \mathrm{~m} \mathrm{~s}^{-2}\right), \rho_{w}$ is a reference seawater density $\left(1025 \mathrm{~kg} \mathrm{~m}^{-3}\right)$, and $(\partial \rho / \partial z)$ is the potential density vertical gradient. $\varepsilon$ and $N^{2}$ were averaged over 1-m depth intervals.

The fluorometer included in the MSS profiler was calibrated with fluorometrically determined chlorophyll $a$ concentrations ranging from 0.03 to $8.6 \mathrm{mg} \mathrm{m}^{-3}$ ( Chl a $=2.255 \times$ fluorescence $-0.527 ; \mathrm{R}^{2}=0.859$, number of samples $=134$ ), obtained during 12 cruises (Mouriño-Carballido et al., 2018).

The inverse buoyancy Reynolds number $\left(\operatorname{Re}_{b}^{-1}\right)$ was used to describe the different energetic regimes characterizing the competition between turbulence and stratification. It was calculated according to:

$R e_{b}^{-1}=\frac{\nu \cdot N^{2}}{\varepsilon}$

where $\nu=1 \cdot 10^{-6} \mathrm{~m}^{2} / \mathrm{s}$ is the kinematic viscosity. Values of $R e_{b}^{-1}$ equal to or less than 0.01 are related to high mixing, whereas values greater than 0.01 are related to low mixing.

Additional information about these cruises is included in Cermeño et al. (2016, DISTRAL-REIMAGE) and Díaz et al. (2019, ASIMUTH).

\subsection{ROMS model}

A four nested grid configuration of the ROMS-AGRIF model was developed, from a $4.5 \mathrm{~km}$ grid $\left(39^{\circ} \mathrm{N}\right.$ to $45^{\circ} \mathrm{N}$ and $12.5^{\circ} \mathrm{W}$ to $\left.6.5^{\circ} \mathrm{W}\right)$ to a $167 \mathrm{~m}$ grid (covering Ría de Vigo), with a standard space factor of 3 between every mother grid and the child grid. The meteorological forcing applied was downloaded and interpolated to the model's grids from the WRF configuration run by Meteogalicia. The river flow data of the main river discharging in the inner part of Ría de Vigo (the OitavénVerdugo River, discharging into San Simón Bay), was calculated by Meteogalicia using the SWAT model. The same calculations were used for all the other rivers flowing into the other Rías Baixas (Lérez, Ulla and Tambre Rivers). Data from the Miño and Duero rivers were taken from the SNIRH (Sistema Nacional de Informaçao de Recursos Hidricos, de Portugal, snirh.apambiente.pt). Bathymetry data from different sources were used. These included GEBCO (General Bathymetric Chart of the Oceans) data as well as data from charts of the Instituto Hidrográfico de la Marina when more precision inside the estuary was needed.

The model was run with all the possible physical forcing parameters, including tides, wind, heat exchange with the atmosphere, etc. The boundary conditions applied came from the Copernicus global simulation $1 / 12^{\circ}$ configuration (marine.copernicus.eu). Daily Copernicus data were interpolated to the model grid and applied using a ten-cell nudging with a tight 1 day momentum and tracer time nudging coefficient.

The results were recorded every hour and the STATIONS option of the model activated at special points, with a frequency of $10 \mathrm{~min}$, for a good comparison with the field data.

\section{Results}

\subsection{Detection and characteristics of TLP in the Galician Rías}

Examination of the weekly CTD-fluorescence profiles obtained by the monitoring program between 2012 and 2015 showed the occurrence of a total of 118 TLP in the 39 monitored stations. This represents a frequency of occurrence of $2 \%$ of the total number of profiles (6408). The highest number of TLP was detected in Ría de Pontevedra (52 TLP), specially at stations P2 (10 TLP) and P4 (11 TLP), located in the middle and outer reaches of the rías respectively, where the frequency of occurrence was about $6 \%$ (Fig. 3). No TLP were detected in shallow (< 

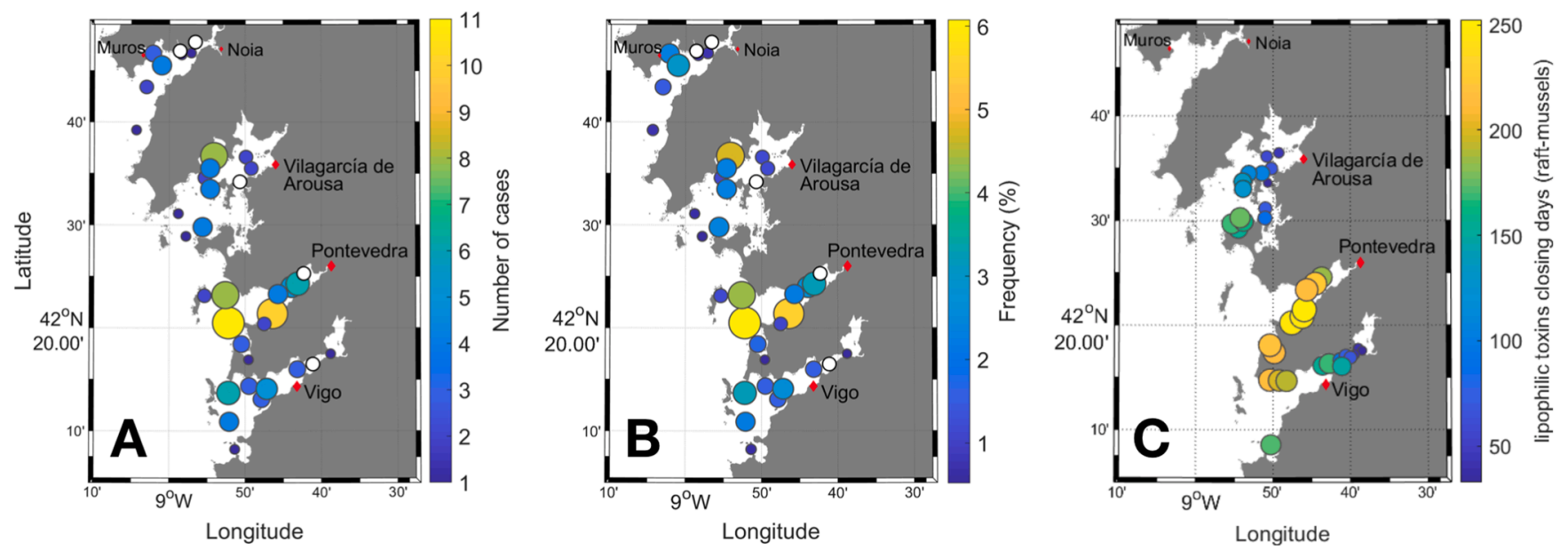

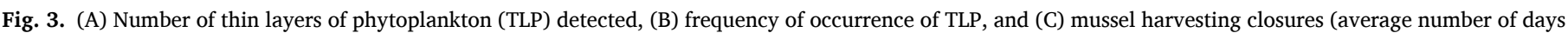

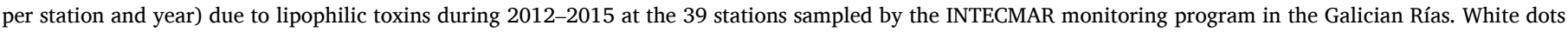
indicate those stations were TLP were not detected.

$10 \mathrm{~m}$ ) waters, at stations M6 and M7 (Ría de Muros-Noia), A5 and A7 (Ría de Arousa), P0 (Ría de Pontevedra) and V4 (Ría de Vigo), in the inner part of the Rías. Ría de Pontevedra was also, according to the INTECMAR data during the same period, the most affected area concerning length of implemented harvesting closures of raft mussels due to lipophilic toxins. Specifically, shellfish production area close to station P2 was prohibited, on average, 242 days per year.

Frequency histograms of TLP features (Fig. 4) showed that $84 \%$ of them were detected during the spring-summer months (May-August), whereas no TLP were detected between November and February. The frequency of occurrence (relative to the number of profiles taken), calculated after excluding those profiles carried out between November and February, would be increased by $50 \%$, from $2 \%$ to $3 \%$, but is still very low. The TLP were characterized by a median intensity 2.5 times greater than the background, associated with shallow pycnoclines (median $=4.5 \mathrm{~m}$ ) and located slightly below these (median $=5.5 \mathrm{~m}$ ).

\subsection{Spatially-extended TLP and their relationship with environmental variables}

During the 4 years of observations, there were 8 cases of se-TLP detection, i.e. TLP observed at least at 5 stations the same sampling
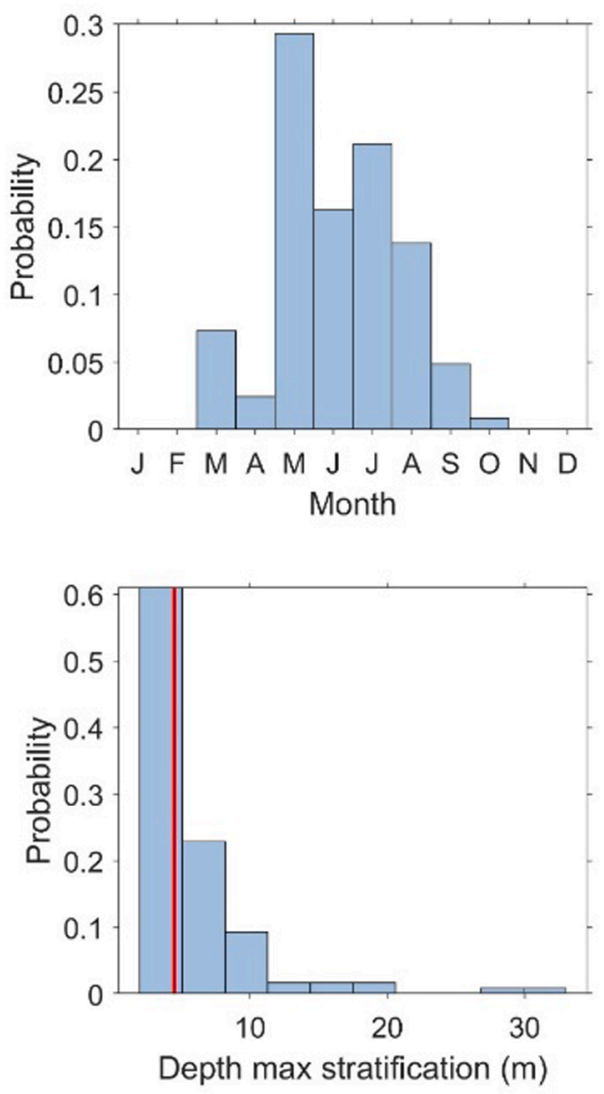

Fig. 4. Frequency histograms of TLP characteristics in the Galician Rías during 2012-2015: A) Month of sampling, B) peak intensity computed as the ratio between the maximal fluorescence value and the background (see methods), C) depth of maximal density stratification, and D) vertical position of the thin layers compared to the depth of maximal density stratification. Vertical red line indicates the value of the median. (For interpretation of the references to color in this figure legend, the reader is referred to the web version of this article.)

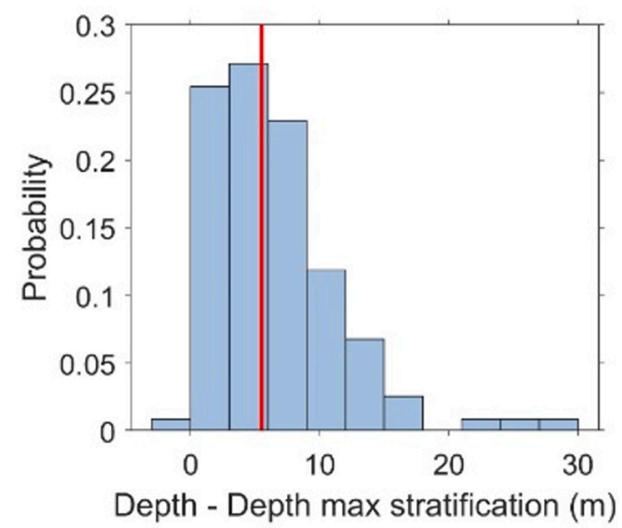


day (Fig. 5). This fact suggests that some of these events had a relatively large spatial distribution in the Rías. Five of them occurred during late spring and summer 2012, one in summer 2013, and another two in summer 2015. The most widespread TLP event, in which 13 stations were affected, was observed on 14 May 2012. One week later, on 21 May 2012, a new se-TLP event was detected, but in this case only 5 stations were affected by the occurrence of TLP. On 25 June 2012, TLP were detected in 10 stations. Next month, on 16 July 2012, in 6 stations. The last event detected in 2012, was on 27 August, when TLP were observed in 5 stations. In 2013, only one se-TLP event, affecting 5 stations, was detected on 12 August. Finally, in 2015 two events were detected affecting 10 stations on 27 July, and 6 stations on 3 August.

In order to investigate the relationship between the occurrence of seTLP events and the environmental variables, a PCA analysis including 26 variables was performed (Fig. 6). In Fig. 6A observations were grouped according to the month when they were conducted, whereas in Fig. 6B groups indicate observations belonging to each of the eight se-TLP events identified. The first two PCA components explained $36.2 \%$ of the variance: the first component (PC1) explained $19.2 \%$ and the second component (PC2) $17.0 \%$ of the variance. The contribution of ten environmental variables to the variance explained by PC1 and PC2 was higher than $5 \%$ each. These variables (in decreasing order) were: surface salinity, meridional wind speed, bottom salinity, nitrate concentration, zonal Ekman transport, silicate, Miño River flow, the proxy for the intrusion of the Miño River plume, relative humidity and haline stratification.

Second and fourth quadrants in the PCA (bottom right and top left, respectively) were associated with the seasonal variability in environmental conditions (Fig. 6A). Specifically, observations located in the fourth quadrant mainly corresponded to the summer period and were positively correlated with relative humidity, long-wavelength radiation, surface temperature, bottom temperature, air temperature, pressure at the fluorescence maximum, thermal stratification, pressure at the stratification maximum and sea level. Observations located in the second quadrant mainly corresponded to early spring and showed a positive correlation with the concentration of all the inorganic nutrients and outflow from local rivers. The first and third quadrants (top right and bottom left, respectively) were influenced by the variability in upwelling-downwelling conditions. The third quadrant was associated with upwelling conditions and observations were positively correlated with surface and bottom salinity, the meridional component of the Ekman transport and short-wavelength radiation. The first quadrant was associated with downwelling conditions and observations were positively correlated with meridional and zonal wind speed, zonal Ekman transport, Miño River flow, the proxy for the intrusion of the Miño River plume, haline stratification and precipitation.

Based on the location of the ellipses centroids, which group each seTLP event (Fig. 6B), the two events detected in spring (14 and 21 May 2012) were located in the second (spring conditions) and first (downwelling) quadrant, respectively. Environmental conditions at the stations influenced by the 21 May event showed a higher variability than those affected by the 14 May event. Among the six events detected in summer, the centroids of the events on 25 June 2012, 27 August 2012 and 27 July 2015 were located in the fourth quadrant (summer conditions) and the environmental conditions of the sampled stations showed a relatively low variability. The event on 3 August 2015, with a centroid also located in the fourth quadrant, exhibited the highest variability. The centroids of the two other summer events (16 July 2012 and 12 August 2013) were located in the third quadrant (upwelling). In summary, the six events detected in summer were associated with summerupwelling conditions, while the other two were associated with springdownwelling.
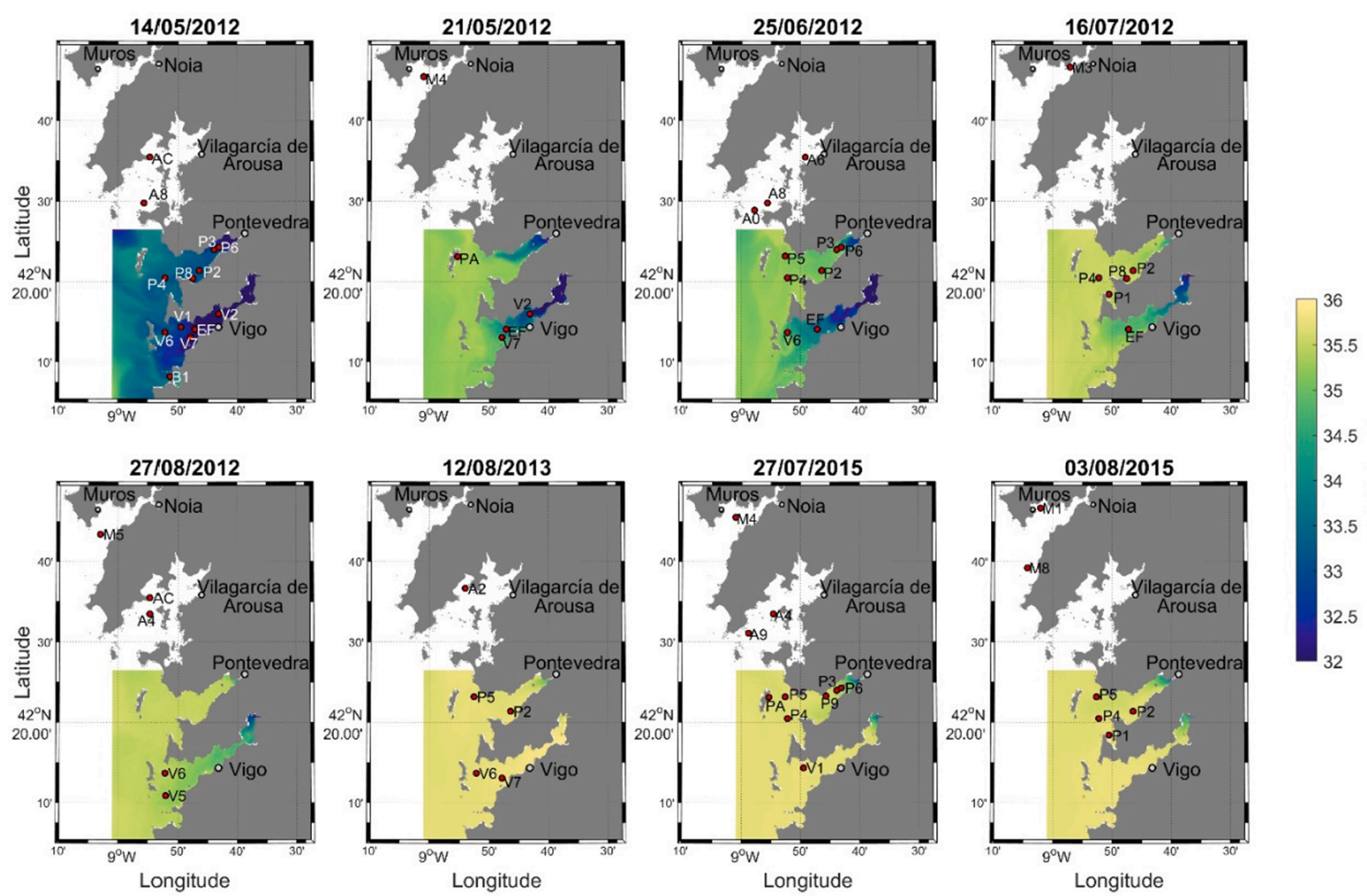

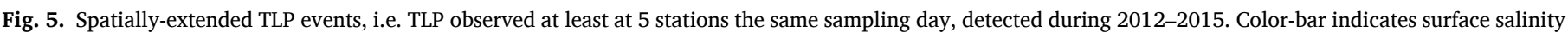

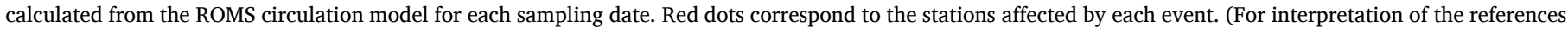
to color in this figure legend, the reader is referred to the web version of this article.) 

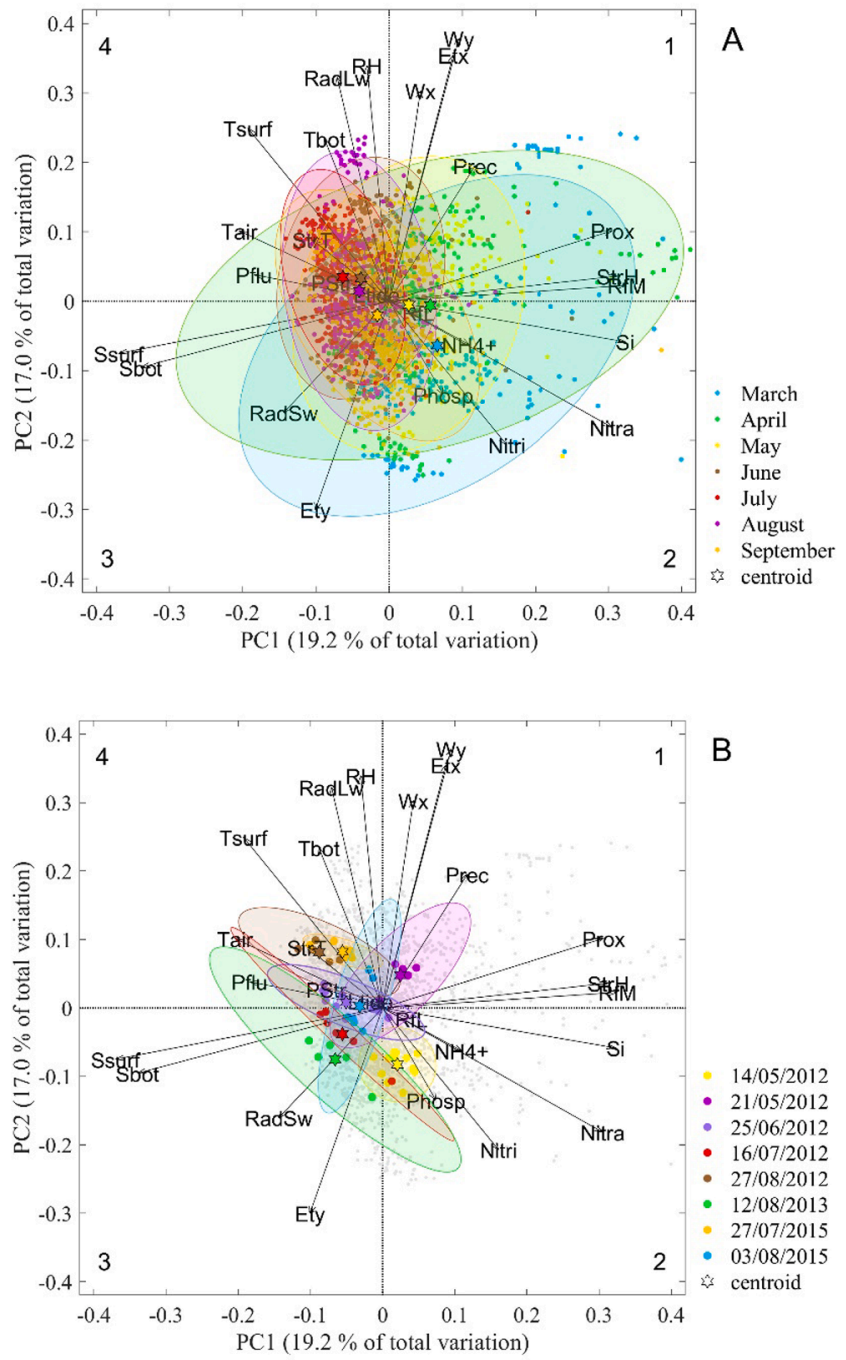

Fig. 6. Principal component analyses (PCA) of environmental conditions observed between 2012 and 2015 in the Rías Baixas. PC1 (dashed vertical line) and PC2 (dashed horizontal line) divide the plot in four quadrants: first (top right), second (bottom right), third (bottom left) and fourth (top left). Vectors are the 26 environmental variables. The length and direction of each vector indicates the strength and sign, respectively, of the correlation. Percentage of variance explained by PC1 and PC2 is also indicated. The stars represent the ellipses centroids. In panel A the $95 \%$ confidence ellipses group observations carried out during the same month, whereas in panel B they group observations belonging to the same spatially-extended TLP event. Small dots in panel A correspond to all the data collected between March and September, whereas in panel B big dots indicate the observation belonging to the same spatiallyextended TLP event.

A logistic regression model was built in order to investigate the relationship between the environmental variables and the presence or absence of se-TLP events. The final selected model included six environmental variables and one interaction term (Table 2). Variables showing a stronger influence on the response (presence of TLP) during the selection process, i.e. classification of variables by order of importance in the backward stepwise regression output, were surface temperature, followed by relative humidity, bottom salinity, the proxy for the intrusion of the Miño River plume, Miño River flow and bottom temperature. With the exceptions of bottom temperature and the interaction term, all variables were positively correlated with the response. According to the McFadden's pseudo $\mathrm{R}^{2}$ (Tonidandel and LeBreton, 2010) the logistic model explained $42 \%$ of the variance.
Table 2

Results from the logistic regression model. Variables included were surface temperature (Tsurf), relative humidity $(\mathrm{RH})$, bottom salinity (Sbot), proxy for the intrusion of the Miño river plume (Prox), Miño river flow (RfM), bottom temperature (Tbot) and the interaction between relative humidity and Miño river flow (RH:RfM). Estimated regression coefficients (Estimate), standard deviation (Std), coefficient divided by standard deviation ( $\mathrm{z}$ value) and the significance value according to the Wald test (p) for each variable are included $(* * \mathrm{p}<0.01 ; * * * \mathrm{p}<0.001)$.

\begin{tabular}{llllll}
\hline & Estimate & Std & Z value & $\mathrm{p}$ & \\
\hline Intercept & -205.50 & 33.95 & -6.05 & $\mathrm{p}<0.001$ & $* * *$ \\
Tsurf & 0.80 & 0.11 & 7.60 & $\mathrm{p}<0.001$ & $* * *$ \\
RH & 11.10 & 3.34 & 3.33 & $\mathrm{p}<0.001$ & $* * *$ \\
Sbot & 5.28 & 0.91 & 5.77 & $\mathrm{p}<0.001$ & $* * *$ \\
Prox & 2.65 & 0.34 & 7.75 & $\mathrm{p}<0.001$ & $* * *$ \\
RfM & 0.09 & 0.01 & 6.43 & $\mathrm{p}<0.001$ & $* * *$ \\
Tbot & -0.54 & 0.18 & -3.03 & $\mathrm{p}<0.01$ & $* *$ \\
RH:RfM & -0.13 & 0.02 & -6.42 & $\mathrm{p}<0.001$ & $* * *$ \\
\hline
\end{tabular}

\subsection{Short-term variability and persistence of TLP events}

The sampling design of the INTECMAR monitoring program, which includes one fluorescence profile per station per week, precluded us from investigating the persistence and temporal variability of the TLP events. This goal was accomplished using data collected during specific oceanographic cruises within the same period.

Observations of MSS profiles from 10 samplings carried out at station EF (central part of Ría de Vigo) in the framework of the DISTRALREIMAGE cruise, between February 2012 and January 2013 (see methods), recorded the hydrographic characteristics of the se-TLP event detected on 14 May 2012 (Fig. 7). This sampling provided evidence of a shallow $(5 \mathrm{~m})$ mixed layer associated with the relatively warm $\left(17.2^{\circ} \mathrm{C}\right)$ and brackish (32.8 psu) surface water detected this day. A TLP with a chlorophyll-a maximum of about $20 \mathrm{mg} \mathrm{m}^{-3}$ and located around $2 \mathrm{~m}$ below the mixed layer depth was observed during the whole MSS sampling time $(3.7 \mathrm{~h})$. This depth is where maximal values of the inverse Reynolds number, due to the intense vertical density stratification, were detected. The phytoplankton community in the TLP was dominated by Gymnodinium sp, Asterionellopsis glacialis and different species of the genus Chaetoceros (Cermeño et al., 2016).

During the ASIMUTH cruise (19-20 June 2013) high frequency observations were carried out with the same microstructure turbulence profiler at station P2 (Ría de Pontevedra) (Fig. 8). At the beginning of the sampling, a TLP with a chlorophyll-a maximum of about $9 \mathrm{mg} \mathrm{m}^{-3}$ was detected at $\sim 18 \mathrm{~m}$ depth associated with weak mixing (high $R e_{b}^{-1}$ ) at the pycnocline. This layer was $26 \mathrm{~h}$ later at $\sim 10 \mathrm{~m}$ depth following intensification of the upwelling and shoaling of the pycnocline (Díaz et al., 2019). The TLP was dissipated between $0 \mathrm{~h}$ and $6 \mathrm{~h}$ when mixing increased (low $\operatorname{Re}_{b}^{-1}$ ) and reappeared a few hours later. Microscopic analysis revealed that the TLP was dominated by Pseudo-nitzschia spp. and Proboscia alata (Díaz et al., 2019).

These results confirm that in the Galician Rías, TLP events could have a relatively large temporal persistence and spatial extent, but they are also under the influence of short-term processes modulating their formation and disappearance over short periods of time.

\subsection{Relationship between TLP occurrence and THAB densities}

We investigated the relationship between the occurrence of TLP and the density of THAB species/genera. Five dinoflagellate species (Dinophysis acuminata, Dinophysis acuta, Dinophysis caudata, Dinophysis sp., and Gymnodinium catenatum) and pennate diatoms of the genus Pseudo-nitzschia occurred at the time TLP were detected (see Table S1 in the supplementary material). However, at least during the study period (2012-2015), only Pseudo-nitzschia spp. and D. acuminata were frequently present ( $\sim 80 \%$ of cases) during TLP events, whereas the 

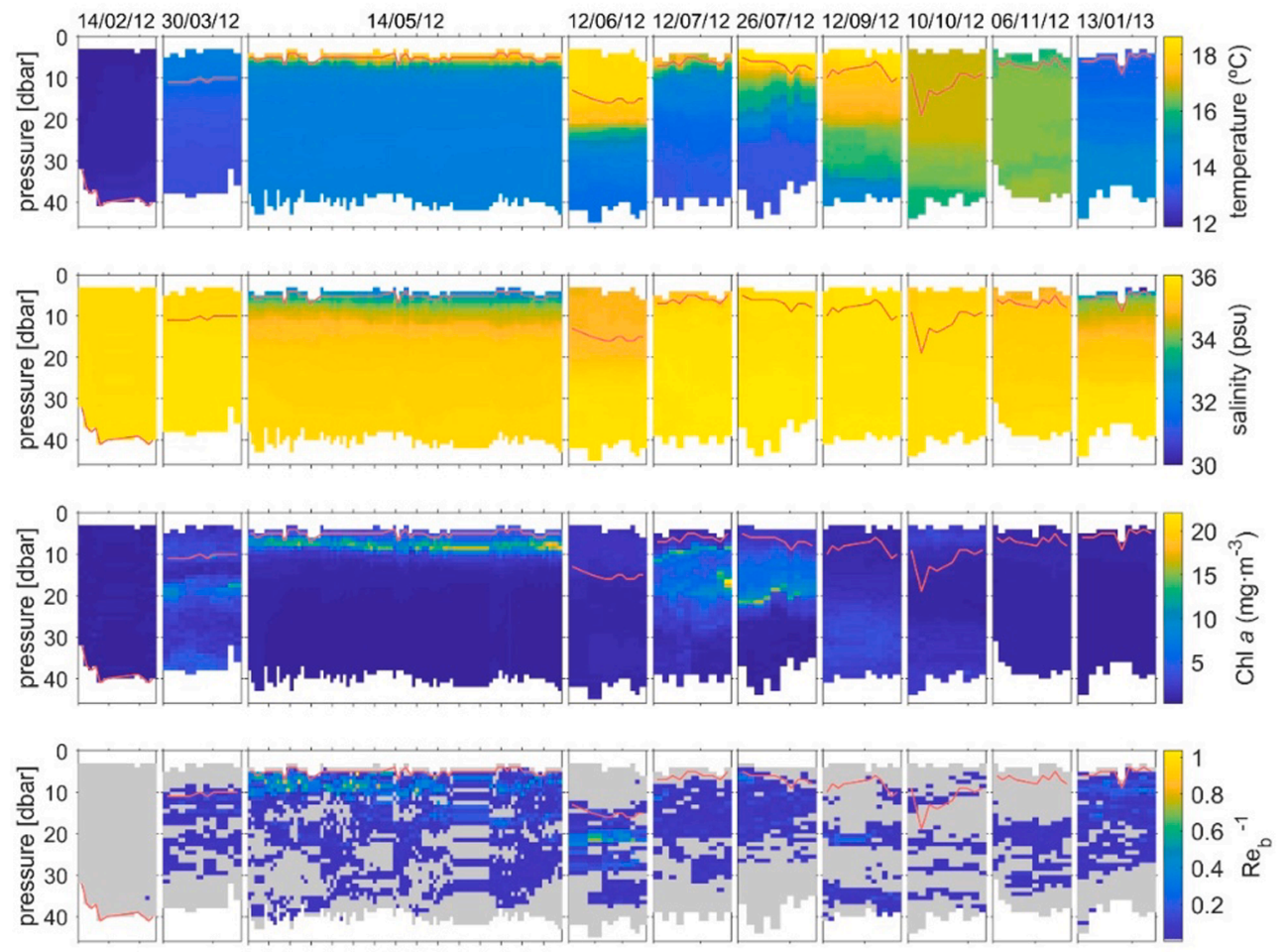

time (minutes)
Fig. 7. Vertical distribution of temperature, salinity, chlorophyll-a and the inverse Reynolds Number $\left(\operatorname{Re}_{\mathrm{b}}^{-1}\right)$, derived from the microstructure turbulence profiler deployed at the EF station (Ría de Vigo) during the DISTRAL-REIMAGE project (February 14, 2012 - January 13, 2013). Areas shaded in grey indicate high mixing $\left(\mathrm{Re}_{\mathrm{b}}^{-1} \leq 0.01\right)$. The first ten profiles of the observations ( $25 \mathrm{~min}$ ) are plotted for each sampling except for May 14, 2012, when the complete observation $(3.7 \mathrm{~h})$ is included. Ticks in the $\mathrm{X}$-axis are plotted every $15 \mathrm{~min}$. Red line indicates the mixed layer depth, determined as the depth where sigma-t differs $>0.125 \mathrm{~kg} \mathrm{~m}^{-3}$ from the surface value. (For interpretation of the references to color in this figure legend, the reader is referred to the web version of this article.)

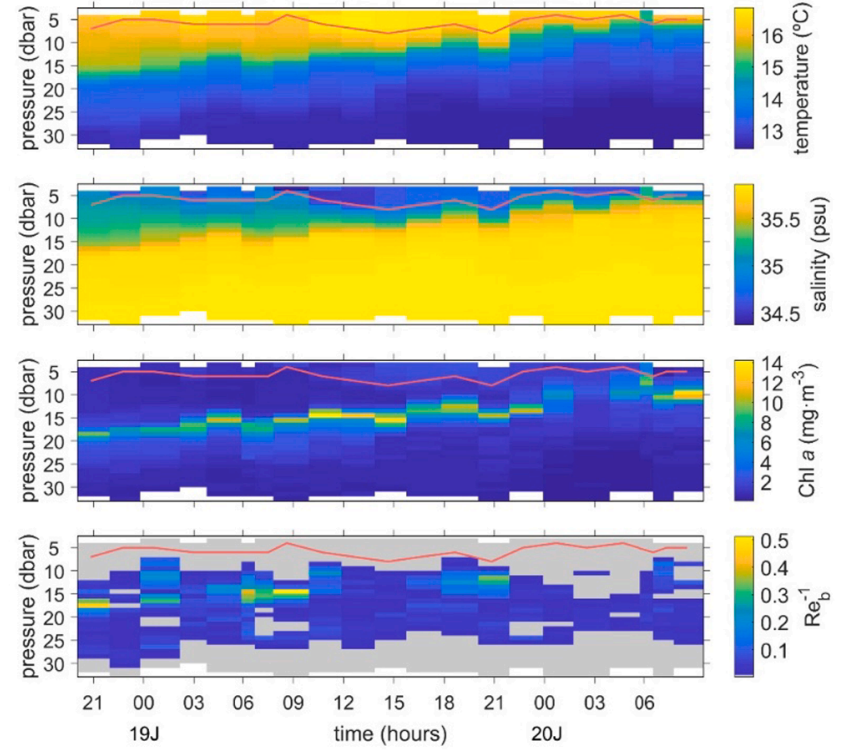

Fig. 8. Vertical distribution of temperature, salinity, chlorophyll and the inverse Reynolds number $\left(\operatorname{Re}_{\mathrm{b}}^{-1}\right)$, derived from the microstructure turbulence profiler deployed at the P2 station (Ría de Pontevedra) during the ASIMUTH cruise (18-20 June 2013). Areas shaded in grey indicate high mixing $\left(\operatorname{Re}_{\mathrm{b}}^{-1} \leq\right.$ 0.01). Red line indicates the mixed layer depth, determined as the depth where sigma-t differs more than $0.125 \mathrm{~kg} \mathrm{~m}^{-3}$ from the surface value. (For interpretation of the references to color in this figure legend, the reader is referred to the web version of this article.)

other species occurred in $<14 \%$ of these events. This led us to focus our analysis on Pseudo-nitzschia spp. and D. acuminata, which are also the main cause of shellfish harvesting closures in the region.

First, we studied the seasonal variability of the monthly average cell densities of Pseudo-nitzschia spp. and D. acuminata. For that purpose, we used the estimated values from all the stations sampled in the four Rías Baixas (Vigo, Pontevedra, Arousa and Muros-Noia) during the period 2012-2017 (Fig. 9). The growth season of D. acuminata exhibited a first maximum in April (1306 [1098, 1573] cells $\mathrm{L}^{-1}$ ) (mean and 95\% confidence intervals between brackets) followed by a second peak of lower magnitude $\left(673[522,1102]\right.$ cells $\left.^{-1}\right)$ in August. Pseudo-nitzschia spp. showed higher densities between June and September, and a peak of 139,020 [104970, 284450] cells $\mathrm{L}^{-1}$ in August. However, this mean value was strongly influenced by the high densities quantified during the exceptional early bloom in 2012 (Díaz et al., 2013). Minimum values of averaged cell densities for both phytoplankton groups occurred between
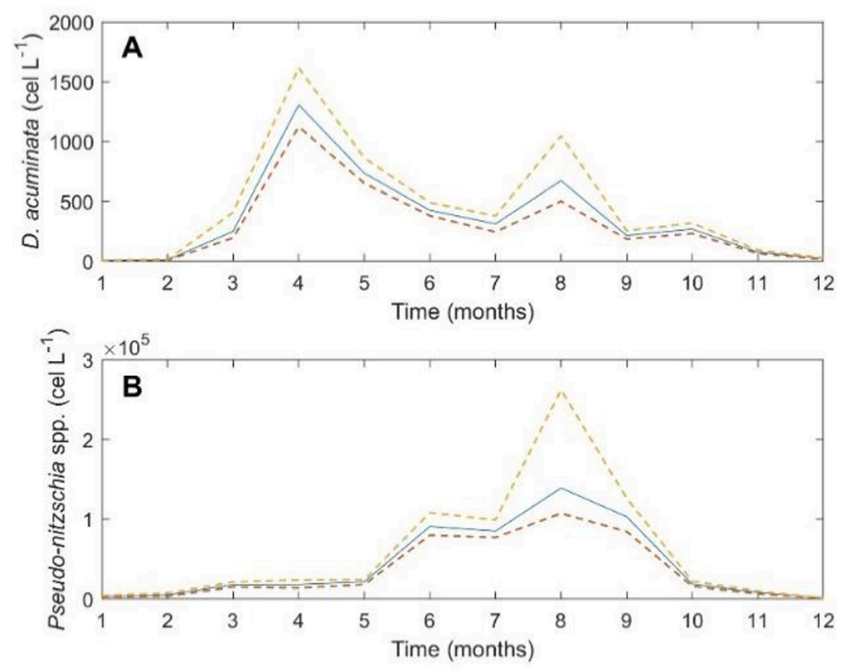

Fig. 9. Monthly mean density (blue line) of (A) D. acuminata and (B) Pseudonitzschia spp. calculated using all the data collected by the INTECMAR monitoring program in all the stations during the period 2012-2017. Dashed lines are the $95 \%$ confidence intervals. 
November and February.

In a broad sense, Pseudo-nitzschia spp. and D. acuminata showed similar seasonal patterns (Figures S1 and S2). However, large differences were observed in the annual average cell density values between stations (Fig. 10, Table S2 in the supplementary material). The highest cell densities for $D$. acuminata $\left(>500\right.$ cells $\mathrm{L}^{-1}$ ) were sampled in Ría de Pontevedra, and the lowest $\left(<100\right.$ cells $\left.\mathrm{L}^{-1}\right)$ in Ría de Arousa. For Pseudo-nitzschia spp. maximum annual average values were found in the outer part of Ría de Arousa and Ría de Muros (>50000 cells L ${ }^{-1}$ ).

To explore the relationship between TLP events and harmful phytoplankton blooms, cell density values co-occurring with detection of TLP were compared with the monthly frequency of distribution, in the form of box-plots, of cell density values quantified at each station (Figs. S1 and S2). According to this analysis, 47\% of the TLP were associated with $D$. acuminata values above the median, $25 \%$ with values above the third quartile and $11 \%$ with outliers (Fig. 11, and Table S3 in the supplementary material). In the case of Pseudo-nitzschia spp. these values were 44,23 and $16 \%$ respectively.

\section{Discussion}

\subsection{Characteristics of the TLP and their relationship with environmental variables}

Our results showed that 118 TLP were observed in the Rías Baixas during the period 2012-2015, a figure representing a low frequency of occurrence $(2 \%)$. These features were more frequently present in the outer part of Ría de Pontevedra (stations P2 and P4), whereas they were not detected in the shallower inner part of the Rías. About $80 \%$ of the TLP occurred between May and August, associated with shallow pycnoclines and located slightly below them in the water column $(5.5 \mathrm{~m})$.

As far as we know, this study represents the first attempt to describe the occurrence and characteristics of TLP, which refer to a particular case of phytoplankton blooms, across different seasons and years. Previous studies have reported the surface area affected by TLP in specific upwelling regions during relatively short periods of time, using different methodologies. Based on Lidar (Laser Imaging Detection and Ranging) observations made off the west coast of Spain and Portugal and in the Bay of Biscay in 1998, Churnside and Donaghay (2009) described that during daylight hours there were TLP in $\sim 1.4 \%$ of the area, but mostly in the upwelling region off the Portugal coast. These observations were carried out during an upwelling relaxation event that followed a month-

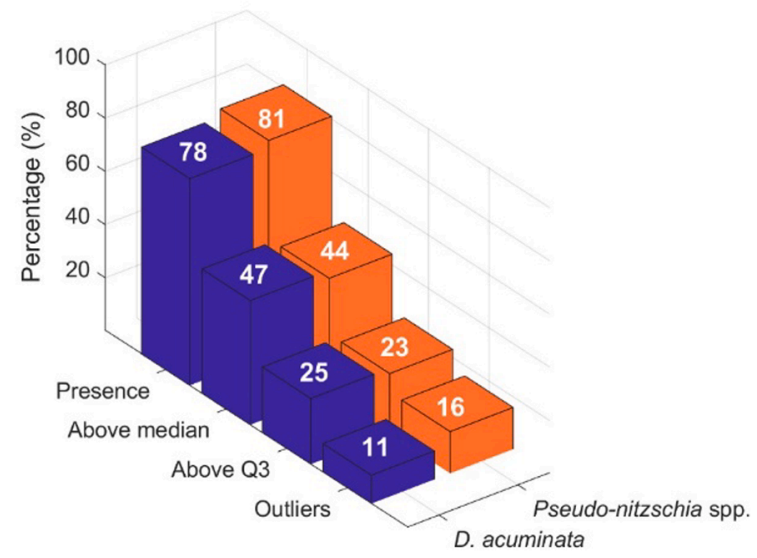

Fig. 11. Percentage of TLP associated with presence, median, third quartile and outliers of Pseudo-nitzschia spp. and Dinophysis acuminata during 2012-2015.

long period of strong upwelling. In the same study, the authors reported a higher occurrence of these features in the Northeast Pacific Ocean, between Washington and Oregon, in summer 2003. They detected TLP in $19 \%$ of the about $8000 \mathrm{~km}$ sampling track in daylight hours, and $6 \%$ at night. The region was under a strong upwelling event before the LIDAR prospection, followed by a heavy fresh-water input from the Columbia River plume. The minimum frequency of TLP $(0.05 \%$ during the day and $0.02 \%$ at night) was found during a strong upwelling event, along a $6000 \mathrm{~km}$ transect off Southern California, in spring 1997. In this case, thin layers were present only during a relatively quiet period before the upwelling event and close to the coast. Using a slow descent rate optical fluorescence profiler in the northern part of Monterey Bay in August-September 2005, Benoit-Bird et al. (2009) detected thin layers in $2 \%$ of the daytime casts.

A higher occurrence of TLP was reported from studies carried out in the Gulf of Aqaba, a semi-enclosed gulf located at the northeast end of the Red Sea, and in East Sound, Orcas Island. Measurements carried out with a Self Contained Autonomous MicroProfiler (SCAMP) in the Gulf of Aqaba in August 2007 reported TLP in $21 \%$ of the profiles. However, authors in this study included phytoplankton layers (from 4 to $21 \mathrm{~m}$ width) far exceeding the established vertical dimensions of a TLP (Steinbuck et al., 2010). In East Sound, Orcas Island, summer 1996, measurements with particulate absorption at $440 \mathrm{~nm}$ detected TLP in
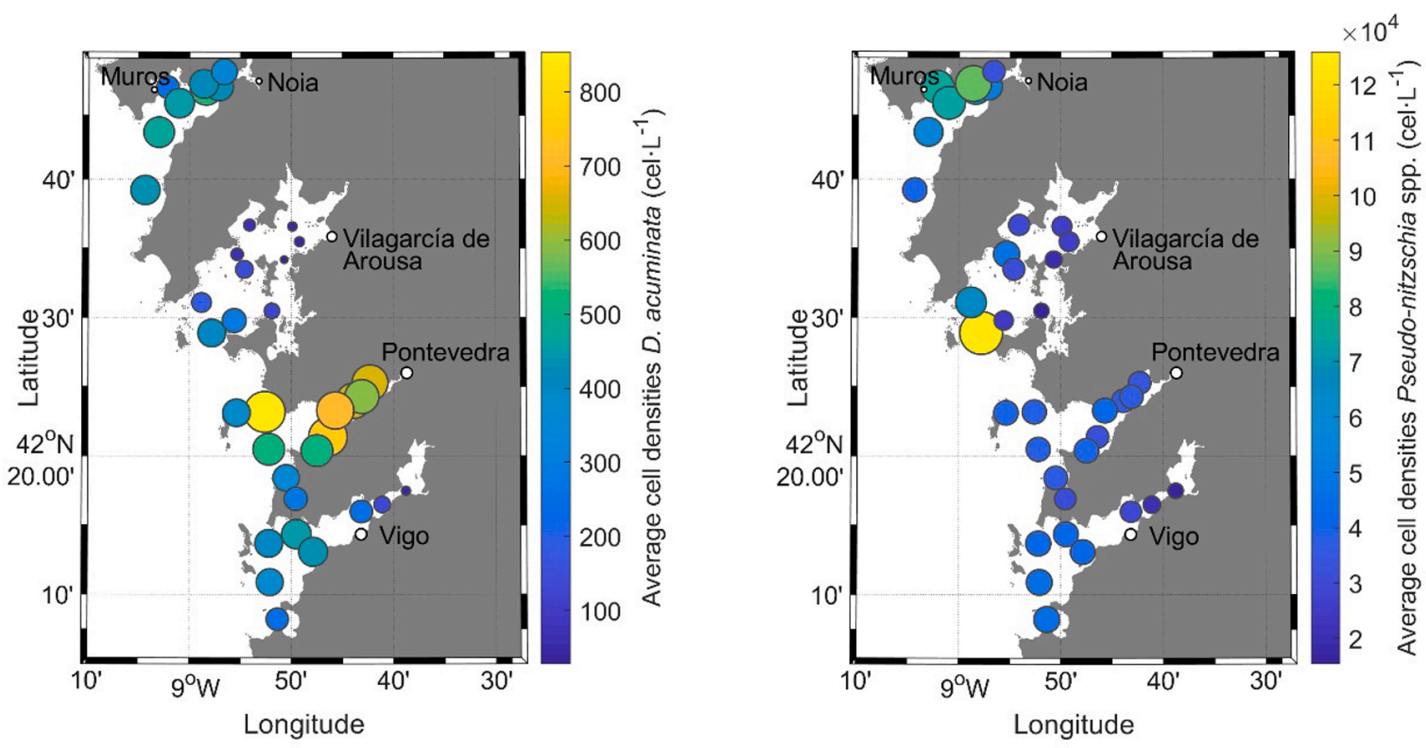

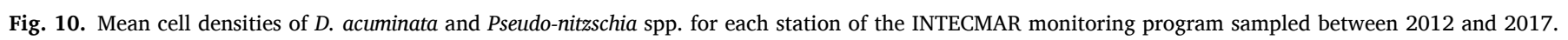


$54 \%$ of the profiles (Dekshenieks et al., 2001).

Our analysis identified eight se-TLP events, i.e. events where at least five stations exhibited TLP the same sampling day, between 2012 and 2015. Two events (14 and 21 May 2012) were associated with springdownwelling conditions, whereas the other six were associated with summer-upwelling. According to the logistic regression, a model including six variables (surface temperature, relative humidity, bottom salinity, a proxy for the intrusion of the Miño river plume, Miño river flow and bottom temperature) and one interaction term (between relative humidity and Miño River flow) explained $42 \%$ of the variance for the probability of appearance of se-TLP events. These results suggest that the occurrence of these events could be related to highly stratified conditions. On the one hand, summer-upwelling observations were positively correlated with thermal stratification since in summer the solar irradiance is higher and the coastal upwelling raises cold water close to the heated surface, thus increasing the vertical gradient of temperature. On the other hand, spring-downwelling observations were in general positively correlated with haline stratification. This indicates that freshwater runoff from local and external rivers (Miño and Duero), both higher in spring, enhance stratification inside the Rías (Gilcoto et al., 2017; Villacieros-Robineau et al., 2013). Downwelling may also introduce the Miño River plume into the Rías (Otero et al., 2008). The relationship between spring se-TLP events and haline stratification was confirmed by results from the ROMS model. They showed that on 14 May 2012, when TLP were detected at 13 stations of the monitoring program, a low salinity surface layer due to freshwater inputs from local rivers was present in the Rías of Vigo and Pontevedra (Reboreda et al., 2018).

Different mechanisms mediated by physical-biological interactions, frequently associated with sharp pycnoclines, have been proposed as drivers for the formation of TLP (Birch et al., 2008; Osborn, 1998). Straining of phytoplankton patches by shear occurs when horizontal scalars gradients are transformed into vertical gradients, due to vertical differences in the horizontal velocity field (Birch et al., 2008; Osborn, 1998). Shear can favor thin layer formation via straining or gyrotactic trapping, but it can also trigger hydrodynamic instabilities and turbulence that dissipate layers. TLP formation can be induced by an active swimming response (taxis) towards a preferred nutrient (Ryan et al., 2010), life prey in the case of mixotrophic dinoflagellates such as Dinophysis species (Velo-Suárez et al., 2014), light (Sullivan et al., 2010a) and salinity levels (Harvey and Menden-Deuer, 2011). Nonmotile phytoplankters can also control their vertical position by regulating their buoyancy through gas vacuoles (Walsh, 2006), and carbohydrate ballasting (Villareal and Carpenter, 2003). The gyrotactic trapping proposed by Durham et al. (2009) describes that vertical shear gradients trigger the formation of thin layers of motile phytoplankton by disrupting their diel vertical migration. Layer formation by in situ growth occurs when growth is stimulated over a narrow depth interval due to favorable light and nutrients levels (Birch et al., 2008). Finally, intrusions can generate TLP through the horizontal transport of nutrients or phytoplankton into adjacent waters (Steinbuck et al., 2010). Thin layers formation in estuarine systems, where salt water containing nutrient-limited marine phytoplankton mixes with nutrient-replete freshwater, has been explained by this mechanism (Kasai et al., 2010).

Despite limitations imposed by the monitoring sampling, our results suggest that the formation of se-TLP events in the Galician Rías Baixas could be related to freshwater advection (Miño River plume and local river discharges) during spring-downwelling and to marked thermal stratification during summer-upwelling. However, multidisciplinary observations covering different stages (appearance, maintenance and dissipation) of thin layers would be needed to identify the biophysical mechanisms responsible for the formation of these features.

\subsection{Relationship between TLP and toxin-producing planktonic microalgae}

Our results showed that the main toxin producers co-occurring with TLP in the Galician Rías and adjacent shelf were Pseudo-nitzschia spp. and Dinophysis acuminata. The highest densities for both phytoplankton groups were found during the upwelling season. These observations agree with previous studies on phytoplankton succession in the area (Figueiras et al., 2002). These studies found that the growth season for Pseudo-nitzschia spp. extended from April to October, reaching maximal cell densities in summer, when water column stratification increased due to solar radiation and intensification of upwelling events (Figueiras et al., 2002). These conditions favor bloom development of "velocity strategists" (r-strategies), such as Pseudo-nitzschia spp., i.e. species with a high nutrient uptake rate well adapted to utilizing high nitrate concentrations during upwelling pulses (Seeyave et al., 2013, 2009).

D. acuminata growth season extended from March to October showing a bi-modal seasonal pattern with peaks in April and August. Previous studies suggested that the first $D$. acuminata cell maximum occurred in June during years with normal upwelling patterns, whereas early-spring peaks occurred during years with anomalous upwelling patterns, i.e. years with a predominance of northerly winds and upwelling events during the previous winter (Díaz et al., 2013). This would have been the case in 2012, when a preceding anomalous winter dominated by upwelling conditions was associated with record high densities of $D$. acuminata and lipophilic toxins concentration in mussels (Díaz et al., 2013). The August maximum coincides with the transition from the upwelling to the downwelling season. These conditions cause changes in the water circulation patterns favoring advection of dinoflagellate shelf populations into the Rías (Figueiras et al., 2008). Predominance of motile species during downwelling phases has been explained by their swimming capability, which enables them to offset the water sinking velocity during the reversed circulation (Figueiras et al., 2002; Fraga, 1998).

According to the analysis of the INTECMAR dataset, Pseudo-nitzschia spp. and D. acuminata were aggregated in thin layers in $23 \%$ and $25 \%$ of the cases respectively, when phytoplankton density values were above the third quartile of the monthly averaged distribution. Previous studies carried out in coastal upwelling systems (McManus et al., 2003, 2008; Rines et al., 2010; Steinbuck et al., 2010) have reported the ability of THAB to aggregate in thin layers. McManus et al. (2003) described the presence of a thin layer in East Sound, Orcas Island, after an upwelling pulse combined with the presence of freshwater from the Fraser River during summer 1998. This feature persisted for three days and was locked to the pycnocline. The phytoplankton community within the layer was dominated by diatoms, including toxin producers such as Pseudo-nitzschia spp., and by Eucampia zodiacus. Later on, in summer 2002, McManus et al. (2008) described another thin layer persisting for 7 days at the base of the pycnocline in Monterrey Bay, California. Phytoplankton composition included toxin producing species of the genus Pseudo-nitzschia. Earlier studies in the same region, in summer 2005, described intense thin layers near the pycnocline at night of the harmful dinoflagellate Akashiwo sanguinea, with Pseudo-nitzschia spp. proliferating above the thin layer (Rines et al. 2010).

Previous studies carried out in the NW Iberia upwelling system provided evidence of the occurrence of TLP in the Galician Rías and their relationship with harmful phytoplankton species. A previous study carried out in late spring 2005 at station P2 in Ría de Pontevedra described the formation of a TLP of Pseudo-nitzschia spp. and other diatoms associated with a steep pycnocline formed after an upwelling pulse (Velo-Suárez et al., 2008). A decimeter-scale segregation of Prorocentrum micans and Dinophysis acuminata populations was described. The population of $D$. acuminata was never found within the pycnocline; instead, it formed patches in the warmer surface waters associated with the diurnal thermocline. A later study carried out at the same station in May-June 2007 described the short-term variability of a thin layer of 
Pseudo-nitzschia spp. modulated by the tidal cycle and quick transitions from upwelling to downwelling conditions (Díaz et al., 2014). These results are consistent with the high-frequency observations reported here at station P2 during the ASIMUTH cruise.

Previous evidence of the relationship between THABs and the occurrence of TLP described cases restricted to short-term samplings. In this regard, our study represents the first multi-year and spatially extended analysis that relates the occurrence of thin layers with the presence of toxin-producing phytoplankton species. However, it is important to bear in mind that, due to the characteristics of the dataset used in this analysis (cell densities determined from depth-integrated samples in the water column), it was not possible to confirm if these phytoplankton groups were in fact present within the thin layers. Pseudo-nitzschia spp. form high density $\left(10^{5}-10^{6}\right.$ cells $\left.\mathrm{L}^{-1}\right)$ blooms, usually associated with peaks in the fluorescence profile, and the detection of thin layers was based on these profiles. Therefore, it is highly probable that in cases when TLP were associated with high values of Pseudo-nitzschia spp., this group was a major component of the thin layer. Dinophysis species form low-density $\left(10^{3}-10^{4}\right.$ cells $\left.\mathrm{L}^{-1}\right)$ populations difficult to be detected in fluorescence profiles except during exceptional blooms with cell densities $>10^{5}$ cell $\mathrm{L}^{-1}$. Nevertheless, they show very patchy vertical distribution and their growth is often associated with water column stability favored by thermohaline stratification (Maestrini, 1998; Reguera et al., 2012). In the Galician Rías Baixas, blooms of Pseudo-nitzschia and D. acuminata often co-occur in time but they are vertically segregated. These scenario was well described during the HABIT 2005 cruise in Ría de Pontevedra (Velo-Suárez et al. 2008) and cruise ASIMUTH 2013 in Ría de Pontevedra, Ría de Vigo and adjacent shelf waters (Díaz et al. 2019). Pseudo-nitzschia cell maximum was found in the pycnocline and that of $D$. acuminata at the surface. The results presented here suggest that in the Galician Rías Baixas, stratified conditions during upwelling favor the development of TLP of Pseudonitzschia spp. in the nutrient-rich pycnocline waters co-occurring with blooms of $D$. acuminata at the nutrient-poorer surface waters.

\section{Conclusions}

According to the results presented here, frequency of occurrence of TLP in the Galician Rías between 2012 and 2015 was low (on average $2 \%)$. However, considering the characteristics of the sampling frequency (once a week), and the evidence that these TLP form and disappear over short periods of time, it is probable that our analysis underestimated the frequency of occurrence of these features in this system. Consistent with previous studies, our analysis showed that most TLP were detected during the spring-summer months, and that these were located slightly below shallow pycnoclines. Eight se-TLP events, i.e., events when more than five stations of the monitoring program were simultaneously influenced by the presence of TLP, were identified in the study period. The six events detected in summer were related to thermal stratification, whereas the two events detected in spring were related to haline stratification. These results indicate that freshwater inputs from local rivers or from the entry of the Miño River plume into the Rías could contribute to the formation of thin layers. The impact of freshwater inputs in the formation of TLP could be through physical mechanisms of increased shear between riverine and oceanic water bodies of contrasting thermohaline properties. In addition, riverine inputs may have a growthpromoting effect on phytoplankton due to the supply of macro and micronutrients (vitamins, trace metals, chelators, etc.) (Barber-Lluch et al., 2019; Tang et al., 2010). Our analysis also indicated TLP were more common in Ría de Pontevedra. This Ría suffers the most frequent harvesting closures due to lipophilic toxins. About $25 \%$ of the TLP in the Rías of Pontevedra and Vigo were associated with increased cell densities of toxin producing Pseudo-nitzschiaspecies and D. acuminata. The characteristics of the sampling methods used (depth integrated hosesamples) did not allow us to discern if these phytoplankton groups were actually present at the precise depth-range of the thin layers.
Nevertheless, results presented here suggest that the occurrence of thin layers could be related with the growth or accumulation of several THAB species in this region. Future high-frequency multidisciplinary observations, covering different stages of TLP development are needed in order to decipher their role in the dynamics of THAB in the Galician Rías Baixas and in other coastal upwelling systems.

\section{Declaration of Competing Interest}

The authors declare that they have no known competing financial interests or personal relationships that could have appeared to influence the work reported in this paper.

\section{Acknowledgments}

We are grateful to the crews of R.V. Mytilus and R.V. Ramón Margalef and to the participants in the two cruises for their help during field work. This research was funded by projects: REMEDIOS (CTM2016-75451-C21-R) to B. Mouriño-Carballido, DISTRAL (CTM2011-25035) to P. Cermeño, and REIMAGE (CTM2011-30155-C03-01) to E. Fernández from the Spanish Ministry of Economy and Competitiveness. ASIMUTH grant to M. Ruiz-Villareal was supported by the $7^{\text {th }}$ Framework Programme of the European Commission (FP7 SPACE.2010.1.1-01 261860). E. Broullón acknowledges a predoctoral fellowship (ED481A2019/288) from Xunta de Galicia, co-funded by FSE Galicia (20142020). B. Fernandez Castro was supported by the Swiss National Science Foundation through grant 200021_179123 (Primary Production Under Oligotrophication in Lakes).

\section{Appendix A. Supplementary data}

Supplementary data to this article can be found online at https://doi. org/10.1016/j.pocean.2020.102449.

\section{References}

Álvarez-Salgado, X.A., Beloso, S., Joint, I., Nogueira, E., Chou, L., Pérez, F.F., Groom, S., Cabanas, J.M., Rees, A.P., Elskens, M., 2002. New production of the NW Iberian shelf during the upwelling season over the period 1982-1999. Deep. Res. Part I Oceanogr. Res. Pap. 49, 1725-1739. https://doi.org/10.1016/S0967-0637(02)00094-8.

Álvarez-Salgado, X.A., Figueiras, F.G., Pérez, F.F., Groom, S., Nogueira, E., Borges, A.V., Chou, L., Castro, C.G., Moncoiffé, G., Ríos, A.F., Miller, A.E.J., Frankignoulle, M., Savidge, G., Wollast, R., 2003. The Portugal coastal counter current off NW Spain: New insights on its biogeochemical variability. Prog. Oceanogr. 56 (2), 281-321. https://doi.org/10.1016/S0079-6611(03)00007-7.

Anderson, C.R., Brzezinski, M.A., Washburn, L., Kudela, R., 2006. Circulation and environmental conditions during a toxigenic Pseudo-nitzschia australis bloom in the Santa Barbara Channel, California. Mar. Ecol. Prog. Ser. 327, 119-133. https://doi, org/10.3354/meps327119.

Arístegui, J., Barton, E.D., Álvarez-Salgado, X.A., Santos, A.M.P., Figueiras, F.G., Kifani, S., Hernández-León, S., Mason, E., Machú, E., Demarcq, H., 2009. Subregional ecosystem variability in the Canary Current upwelling. Prog. Oceanogr. 83, 33-48. https://doi.org/10.1016/j.pocean.2009.07.031.

Bakun, A., 1973. Coastal upwelling indexes, west coast of north America. NOAA Technical Report NMF 671.

Barber-Lluch, E., Hernández-Ruiz, M., Prieto, A., Fernández, E., Teira, E., 2019. Role of vitamin B12 in the microbial plankton response to nutrient enrichment. Mar. Ecol. Prog. Ser. 626, 29-42. https://doi.org/10.3354/meps13077.

Barton, E.D., Torres, R., Figueiras, F.G., Gil-Coto, M., Largier, J., 2016. Surface water subduction during a downwelling event in a semienclosed bay. J. Geophys. Res. Ocean. 121, 7088-7107. https://doi.org/10.1002/2016JC011950.

Benoit-Bird, K.J., Cowles, T.J., Wingard, C.E., 2009. Edge gradients provide evidence of ecological interactions in planktonic thin layers. Limnol. Oceanogr. 54, 1382-1392. https://doi.org/10.4319/lo.2009.54.4.1382.

Birch, D.A., Young, W.R., Franks, P.J.S., 2008. Thin layers of plankton: Formation by shear and death by diffusion. Deep. Res. Part I Oceanogr. Res. Pap. 55, 277-295. https://doi.org/10.1016/j.dsr.2007.11.009.

Blanco, J., Arévalo, F., Correa, J., Moroño, Á., 2019. Lipophilic toxins in Galicia (NW Spain) between 2014 and 2017: Incidence on the main molluscan species and analysis of the monitoring efficiency. Toxins (Basel). 11, 612. https://doi.org/ $10.3390 /$ toxins11100612.

Bravo, I., Fraga, S., Isabel Figueroa, R., Pazos, Y., Massanet, A., Ramilo, I., 2010. Bloom dynamics and life cycle strategies of two toxic dinoflagellates in a coastal upwelling system (NW Iberian Peninsula). Deep. Res. Part II Top. Stud. Oceanogr. 57, 222-234. https://doi.org/10.1016/j.dsr2.2009.09.004. 
Cermeño, P., Chouciño, P., Fernández-Castro, B., Figueiras, F.G., Marañón, E., Marrasé, C., Mouriño-Carballido, B., Pérez-Lorenzo, M., Rodríguez-Ramos, T., Teixeira, I.G., Vallina, S.M., 2016. Marine Primary Productivity Is Driven by a Selection Effect. Front. Mar. Sci. 3 https://doi.org/10.3389/fmars.2016.00173.

Churnside, J.H., Donaghay, P.L., 2009. Thin scattering layers observed by airborne lidar. ICES J. Mar. Sci. 66, 778-789. https://doi.org/10.1093/icesjms/fsp029.

Cook, R., Weisberg, S., 1982. Residuals and influence in regression. Chapman Hall/CRC, New York, USA.

Crawford, D., 2007. Mesodinium rubrum: the phytoplankter that wasn't. Mar. Ecol. Prog. Ser. 58, 161-174. https://doi.org/10.3354/meps058161.

Crespo, B.G., Figueiras, F.G., Porras, P., Teixeira, I.G., 2006. Downwelling and dominance of autochthonous dinoflagellates in the NW Iberian margin: The example of the Ría de Vigo. Harmful Algae 5, 770-781. https://doi.org/10.1016/J. HAL. 2006.03.006.

Dekshenieks, M.M., Donaghay, P.L., Sullivan, J.M., Rines, J.E.B., Osborn, T.R., Twardowski, M.S., 2001. Temporal and spatial occurrence of thin phytoplankton layers in relation to physical processes. Mar. Ecol. Prog. Ser. 223, 61-71. https://doi. org/10.3354/meps223061.

Des, M., DeCastro, M., Sousa, M.C., Dias, J.M., Gómez-Gesteira, M., 2019. Hydrodynamics of river plume intrusion into an adjacent estuary: The Minho River and Ria de Vigo. J. Mar. Syst. 189, 87-97. https://doi.org/10.1016/j. jmarsys.2018.10.003.

Díaz, P.A., Reguera, B., Ruiz-Villarreal, M., Pazos, Y., Velo-Suárez, L., Berger, H., Sourisseau, M., 2013. Climate variability and oceanographic settings associated with interannual variability in the initiation of Dinophysis acuminata blooms. Mar. Drugs 11, 2964-2981. https://doi.org/10.3390/md11082964.

Díaz, P.A., Ruiz-Villarreal, M., Mouriño-Carballido, B., Fernández-Pena, C., Riobó, P. Reguera, B., 2019. Fine scale physical-biological interactions during a shift from relaxation to upwelling with a focus on Dinophysis acuminata and its potential ciliate prey. Prog. Oceanogr. 175, 309-327. https://doi.org/10.1016/j. pocean.2019.04.009.

Díaz, P.A., Ruiz-Villarreal, M., Velo-Suárez, L., Ramilo, I., Gentien, P., Lunven, M., Fernand, L., Raine, R., Reguera, B., 2014. Tidal and wind-event variability and the distribution of two groups of Pseudo-nitzschia species in an upwelling-influenced Ría. Deep. Res. Part II Top. Stud. Oceanogr. 101, 163-179. https://doi.org/10.1016/j. dsr2.2013.09.043.

Durham, W.M., Kessler, J.O., Stocker, R., 2009. Disruption of vertical motility by shear triggers formation of thin phytoplankton layers. Science 323, 1067-1070. https:// doi.org/10.1126/science.1167334.

Durham, W.M., Stocker, R., 2012. Thin Phytoplankton Layers: Characteristics, Mechanisms, and Consequences. Ann. Rev. Mar. Sci. 4, 177-207. https://doi.org/ 10.1146/annurev-marine-120710-100957.

Escalera, L., Pazos, Y., Dolores Doval, M., Reguera, B., 2012. A comparison of integrated and discrete depth sampling for monitoring toxic species of Dinophysis. Mar. Pollut. Bull. 64, 106-113. https://doi.org/10.1016/j.marpolbul.2011.10.015.

Escalera, L., Reguera, B., Moita, T., Pazos, Y., Cerejo, M., Cabanas, J.M., RuizVillarreal, M., 2010. Bloom dynamics of Dinophysis acuta in an upwelling system: In situ growth versus transport. Harmful Algae 9, 312-322. https://doi.org/10.1016/j. hal.2009.12.002.

Figueiras, F.G., Labarta, U., Reiriz, M.J.F., 2002. Coastal upwelling, primary production and mussel growth in the Rías Baixas of Galicia. In: Sustainable Increase of Marine Harvesting: fundamental mechanisms and new concepts. Springer, Netherlands, Dordrecht, pp. 121-131.

Figueiras, F.G., Miranda, A., Riveiro, I., Vergara, A., Guisande, C., 2008. El plancton de la Ría de Vigo. La Ría de Vigo: Una Aproximación Integral Al Ecosistema Marino de La Ría de Vigo. 111-152. https://doi.org/10.1007/s13398-014-0173-7.2.

Fraga, F., 1981. Upwelling off the Galician coast, Northwest Spain. Coast. Estuar. Sci. Coast. Upwelling 1, 176-182. https://doi.org/10.1029/co001p0176.

Fraga, S., 1998. Pseudo-nitzschia species isolated from Galician waters: toxicity, DNA content and lectin binding assay. Harmful Algae 270-273.

Fraga, S., Anderson, D.M., Bravo, I., Reguera, B., Steidinger, K.A., Yentsch, C.M., 1988. Influence of upwelling relaxation on dinoflagellates and shellfish toxicity in Ria de Vigo. Spain. Estuar. Coast. Shelf Sci. 27, 349-361. https://doi.org/10.1016/02727714(88)90093-5.

Fryxell, G.A., Villac, M.C., Shapiro, L.P., 1997. The occurrence of the toxic diatom genus Pseudo-nitzschia (Bacillariophyceae) on the West Coast of the USA, 1920-1996: A review. Phycologia 36, 419-437. https://doi.org/10.2216/i0031-8884-36-6-419.1.

GEOHAB, 2008. Global Ecology and Oceanography of Harmful Algal Blooms, GEOHAB core research project: HABs in upwelling systems. France and Newar, Delaware, USA, Paris.

Gilcoto, M., Largier, J.L., Barton, E.D., Piedracoba, S., Torres, R., Graña, R., AlonsoPérez, F., Villacieros-Robineau, N., Granda, F., 2017. Rapid response to coastal upwelling in a semienclosed bay. Geophys. Res. Lett. 44, 2388-2397. https://doi. org/10.1002/2016GL072416.

Hansen, H.P., Grassoff, K., 1983. Automated chemical analysis. In: Grasshoff, K., M. Ehrhardt, M., Kremling, K. (Ed.), Methods of Seawater Analysis. Verlag Chemie, Weinheim, pp. 347-395.

Harvey, E.L., Menden-Deuer, S., 2011. Avoidance, movement, and mortality: The interactions between a protistan grazer and Heterosigma akashiwo, a harmful algal bloom species. Limnol. Oceanogr. 56, 371-378. https://doi.org/10.4319/ 10.2011.56.1.0371.

Hasle, G., 1994. Pseudo-nitzschia as a genus distinct from Nitzschia. J. Phycol. 30, 1036-1039.

Hosmer, D.W., Lemeshow, S., Sturdivant, R.X., 2013. Introduction to the Logistic Regression Model. Applied Logistic Regression. Wiley Series in Probability and Statistics 398, 1-33. https://doi.org/10.1002/9781118548387.ch1.
James, G., Witten, D., Hastie, T., Tibshirani, R., 2013. An Introduction to Statiscal Learning with Applications in R. Springer. https://doi.org/10.1016/j. peva.2007.06.006.

Jones, D.L., 2015. Fathom Toolbox for Matlab: software for multivariate ecological and oceanographic data analysis.

Kasai, A., Kurikawa, Y., Ueno, M., Robert, D., Yamashita, Y., 2010. Salt-wedge intrusion of seawater and its implication for phytoplankton dynamics in the Yura Estuary. Japan. Estuar. Coast. Shelf Sci. 86, 408-414. https://doi.org/10.1016/j. ecss. 2009.06.001.

Labarta, U., Fernández-Reiriz, M.J., 2019. The Galician mussel industry: Innovation and changes in the last forty years. Ocean Coast. Manag. 167, 208-218. https://doi.org/ 10.1016/j.ocecoaman.2018.10.012.

Lasker, R., 1975. Field criteria for survival of anchovy larvae: the relation between inshore chlorophyll maximum layers and successful first feeding. Fish. Bull. 73, 453-462.

Lelong, A., Hégaret, H., Soudant, P., Bates, S.S., 2012. Pseudo-nitzschia (Bacillariophyceae) species, domoic acid and amnesic shellfish poisoning: revisiting previous paradigms. Phycologia 51, 168-216. https://doi.org/10.2216/11-37.1.

Lindahl, O., 1986. A dividable hose for phytoplankton sampling. ICES Report of the Working Group on Exceptional algal blooms 50, 26.

Maestrini, S.Y., 1998. Bloom dynamics and ecophysiology of Dinophysis spp. In: NATO ASI Series, Series G, Ecological Science. Springer-Verlag, Berlin, Heidelberg, New York, pp. 243-266.

McManus, M., Alldredge, A., Barnard, A., Boss, E., Case, J., Cowles, T., Donaghay, P., Eisner, L., Gifford, D., Greenlaw, C., Herren, C., Holliday, D., Johnson, D., MacIntyre, S., McGehee, D., Osborn, T., Perry, M., Pieper, R., Rines, J., Smith, D., Sullivan, J., Talbot, M., Twardowski, M., Weidemann, A., Zaneveld, J., 2003. Characteristics, distribution and persistence of thin layers over a 48 hour period. Mar. Ecol. Prog. Ser. 261, 1-19. https://doi.org/10.3354/meps261001.

McManus, M.A., Kudela, R.M., Silver, M.W., Steward, G.F., Donaghay, P.L., Sullivan, J. M., 2008. Cryptic blooms: Are thin layers the missing connection? Estuaries and Coasts 31, 396-401. https://doi.org/10.1007/s12237-007-9025-4.

Míguez, A., Fernández, L., Fraga, S., 1996. First detection of domoic acid in Galicia (NW of Spain). In: Yasumoto, T., Oshima, Y., Fukuyo, Y. (Eds.), Harmful and Toxic Algal Blooms. Paris, pp. 143-145.

Moroño, Á., Pazos, Y., Doval, M.D., 2008. Oceanográfico 2008 anuario de galicia. INTECMAR.

Mouriño-Carballido, Beatriz, Blazquez, Mariña, Fernández-Castro, Bieito, AguiarGonzález, B, Chouciño, P, Graña, R, Villamaña, M, Moreira-Coello, V, Otero, José Luis, 2018. How large is nitrate turbulent diffusion into the euphotic zone? Encuentro de Oceanografía Física, Vigo (Spain).

Osborn, T., 1998. Finestructure, Microstructure, and Thin Layers. Oceanography 11, 36-43. https://doi.org/10.5670/oceanog.1998.13.

Otero, P., Ruiz-Villarreal, M., Peliz, A., 2008. Variability of river plumes off Northwest Iberia in response to wind events. J. Mar. Syst. 72, 238-255. https://doi.org/ 10.1016/j.jmarsys.2007.05.016.

Park, M., Kim, S., Kim, H., Myung, G., Kang, Y., Yih, W., 2006. First successful culture of the marine dinoflagellate Dinophysis acuminata. Aquat. Microb. Ecol. 45, 101-106. https://doi.org/10.3354/ame045101.

Pitcher, G.C., 1990. Phytoplankton seed populations of the Cape Peninsula upwelling plume, with particular reference to resting spores of Chaetoceros (bacillariophyceae) and their role in seeding upwelling waters. Estuar. Coast. Shelf Sci. 31, 283-301. https://doi.org/10.1016/0272-7714(90)90105-Z.

Prandke, H., Holtsch, K., Stips, A., 2000. MITEC technology development: the microstructure/turbulence measuring system MSS. Sp. Appl, Inst.

Prandke, H., Stips, A., 1998. Test measurements with an operational microstructureturbulence profiler: Detection limit of dissipation rates. Aquat. Sci. 60, 191. https:// doi.org/10.1007/s000270050036.

Reboreda, R., Souto, C., Mouriño-Carballido, B., Chouciño, P., Gil-Coto, M., FernándezCastro, B., Nogueira, E., 2018. Study of two major events of thin layers of phytoplankton in the Galician Rías using a 3D Ocean Model, in: VI International Symposium on Marine Sciences, Encuentro de Oceanografía Física. Vigo.

Reguera, B., Riobó, P., Rodríguez, F., Díaz, P.A., Pizarro, G., Paz, B., Franco, J.M., Blanco, J., 2014. Dinophysis toxins: Causative organisms, distribution and fate in shellfish. Mar. Drugs 12, 394-461. https://doi.org/10.3390/md12010394.

Reguera, B., Velo-Suárez, L., Raine, R., Park, M.G., 2012. Harmful Dinophysis species: A review. Harmful Algae 14, 87-106. https://doi.org/10.1016/j.hal.2011.10.016.

Rines, J.E.B., McFarland, M.N., Donaghay, P.L., Sullivan, J.M., 2010. Thin layers and species-specific characterization of the phytoplankton community in Monterey Bay, California, USA. Cont. Shelf Res. 30, 66-80. https://doi.org/10.1016/j. csr.2009.11.001.

Ríos, A.F., Pérez, F.F., Fraga, F., 1992. Water masses in the upper and middle North Atlantic Ocean east of the Azores. Deep Sea Res. Part A. Oceanogr. Res. Pap. 39, 645-658. https://doi.org/10.1016/0198-0149(92)90093-9.

Ryan, J., McManus, M., Paduan, J., Chavez, F., 2008. Phytoplankton thin layers caused by shear in frontal zones of a coastal upwelling system. Mar. Ecol. Prog. Ser. 354, 21-34. https://doi.org/10.3354/meps07222.

Ryan, J.P., McManus, M.A., Sullivan, J.M., 2010. Interacting physical, chemical and biological forcing of phytoplankton thin-layer variability in Monterey Bay. California. Cont. Shelf Res. 30, 7-16. https://doi.org/10.1016/j.csr.2009.10.017.

Seeyave, S., Probyn, T., Álvarez-Salgado, X.A., Figueiras, F.G., Purdie, D.A., Barton, E.D., Lucas, M., 2013. Nitrogen uptake of phytoplankton assemblages under contrasting upwelling and downwelling conditions: The Ría de Vigo. NW Iberia. Estuar. Coast. Shelf Sci. 124, 1-12. https://doi.org/10.1016/J.ECSS.2013.03.004.

Seeyave, S., Probyn, T., Pitcher, G., Lucas, M., Purdie, D., 2009. Nitrogen nutrition in assemblages dominated by Pseudo-nitzschia spp., Alexandrium catenella and 
Dinophysis acuminata off the west coast of South Africa. Mar. Ecol. Prog. Ser. 379, 91-107. https://doi.org/10.3354/meps07898.

Sellner, K.G., Doucette, G.J., Kirkpatrick, G.J., 2003. Harmful algal blooms: Causes, impacts and detection. J. Ind. Microbiol. Biotechnol. 30 (7), 383-406. https://doi. org/10.1007/s10295-003-0074-9.

Sordo, I., Barton, E.D., Cotos, J.M., Pazos, Y., 2001. An inshore poleward current in the NW of the Iberian Peninsula detected from satellite images, and its relation with G. catenatum and D. acuminata blooms in the Galician Rias. Estuar. Coast. Shelf Sci. 53, 787-799. https://doi.org/10.1006/ECSS.2000.0788.

Steinbuck, J.V., Genin, A., Monismith, S.G., Koseff, J.R., Holzman, R., Labiosa, R.G., 2010. Turbulent mixing in fine-scale phytoplankton layers: Observations and inferences of layer dynamics. Cont. Shelf Res. 30, 442-455. https://doi.org/ 10.1016/j.csr.2009.12.014.

Sullivan, J.M., Donaghay, P.L., Rines, J.E.B.B., Percy, L.D., Rines, J.E.B.B., 2010a. Coastal thin layer dynamics: Consequences to biology and optics. Cont. Shelf Res. 30, 50-65. https://doi.org/10.1016/J.CSR.2009.07.009.

Sullivan, J.M., McManus, M.A., Cheriton, O.M., Benoit-Bird, K.J., Goodman, L., Wang, Z., Ryan, J.P., Stacey, M., Van Holliday, D., Greenlaw, C., Moline, M.A., McFarland, M., 2010b. Layered organization in the coastal ocean: An introduction to planktonic thin layers and the LOCO project. Cont. Shelf Res. 30, 1-6. https://doi.org/10.1016/j. csr.2009.09.001.

Tang, Y.Z., Koch, F., Gobler, C.J., 2010. Most harmful algal bloom species are vitamin B1 and B12 auxotrophs. Proc. Natl. Acad. Sci. U. S. A. 107, 20756-20761. https://doi. org/10.1073/pnas.1009566107.

Tilstone, G., Figueiras, F., Fermín, E., Arbones, B., 1999. Significance of nanophytoplankton photosynthesis and primary production in a coastal upwelling system (Ría de Vigo, NW Spain). Mar. Ecol. Prog. Ser. 183, 13-27. https://doi.org/ 10.3354/meps183013.

Tonidandel, S., LeBreton, J.M., 2010. Determining the relative importance of predictors in logistic regression: an extension of relative weight analysis. Organ. Res. Methods 13, 767-781. https://doi.org/10.1177/1094428109341993.
Trainer, V.L., Bates, S.S., Lundholm, N., Thessen, A.E., Cochlan, W.P., Adams, N.G., Trick, C.G., 2012. Pseudo-nitzschia physiological ecology, phylogeny, toxicity, monitoring and impacts on ecosystem health. Harmful Algae 14, 271-300. https:// doi.org/10.1016/j.hal.2011.10.025.

Trainer, V.L., Pitcher, G.C., Reguera, B., Smayda, T.J., 2010. The distribution and impacts of harmful algal bloom species in eastern boundary upwelling systems. Prog. Oceanogr. 85, 33-52. https://doi.org/10.1016/j.pocean.2010.02.003.

Velo-Suárez, L., Fernand, L., Gentien, P., Reguera, B., 2010. Hydrodynamic conditions associated with the formation, maintenance and dissipation of a phytoplankton thin layer in a coastal upwelling system. Cont. Shelf Res. 30, 193-202. https://doi.org/ 10.1016/j.csr.2009.11.002.

Velo-Suárez, L., González-Gil, S., Gentien, P., Lunven, M., Bechemin, C., Fernand, L., Raine, R., Reguera, B., 2008. Thin layers of Pseudo-nitzschia spp. and the fate of Dinophysis acuminata during an upwelling-downwelling cycle in a Galician Ría. Limnol. Oceanogr. 53, 1816-1834.

Velo-Suárez, L., González-Gil, S., Pazos, Y., Reguera, B., 2014. The growth season of Dinophysis acuminata in an upwelling system embayment: A conceptual model based on in situ measurements. Deep. Res. Part II Top. Stud. Oceanogr. 101, 141-151. https://doi.org/10.1016/j.dsr2.2013.03.033.

Villacieros-Robineau, N., Herrera, J.L., Castro, C.G., Piedracoba, S., Roson, G., 2013. Hydrodynamic characterization of the bottom boundary layer in a coastal upwelling system (Ría de Vigo, NW Spain). Cont. Shelf Res. 68, 67-79. https://doi.org/ 10.1016/j.csr.2013.08.017.

Villareal, T.A., Carpenter, E.J., 2003. Buoyancy regulation and the potential for vertical migration in the oceanic cyanobacterium Trichodesmium. Microb. Ecol. 45, 1-10. https://doi.org/10.1007/s00248-002-1012-5.

Walsh, J.J., 2006. Relative Importance of Habitat Variables in Predicting the Distribution of Phytoplankton at the Ecotone of the Antarctic Upwelling Ecosystem. Ecol. Monogr. 41, 291-309. https://doi.org/10.2307/1948495.

Wooster, W.S., Bakun, A., McLain, D.R., 1976. The seasonal upwelling cycle along the eastern boundary of the North Atlantic. J. Mar. Res. 34, 131-141. 